In the interest of prompt distribution, this LAMS report was not edited by the Technical Information staff.

Printed in the United States of America. Available from National Technical Information Service

U. S. Department of Commerce 5285 Port Royal Road Springfield, Virginia 22151

Price: Printed Copy $\$ 3.00$; Microfiche $\$ 0.95$ 
LA-5097-MS

Intormat Report

UC. 41

ISSUED: November 1972

\section{Los Alamos Land Areas Environmental Radiation Survey 1972}

by

LaMar J. Johnson

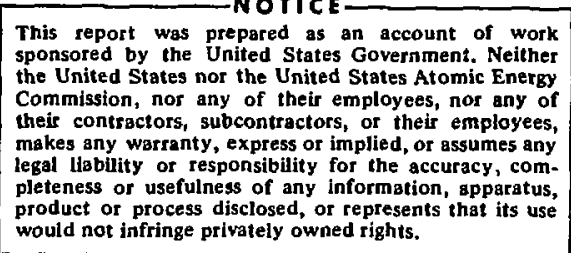




\begin{abstract}
The details of an environmental radiological evaluation on about 5,500 acres in eight parcels of land owned by the United States Atomic Energy Commission (USAEC) in Los Alamos County, New Mexico, are presented in this report. The environmental aseessment of these real properties included a careful search of the administrative records of the Los Alamos Scientific Laboratory (LASL) to determine the extent the land might have been used or involved in the Laboratory's activities, extensive measurements of the radiation levels in the field, and radiochemical analysis of numerous soil and vegetation samples. A new portable radiation measurement instrument, designated as the Los Alamcs Field Pulse Height Analyzer, was developed and used for this study. This analyzer proved to be valuable in documenting the low levels of radioactivity encountered. The results of the study showed that all measured values were comparable to reported worldwide levels, and that no radiation or radioactive contamination observations were encountered that are of radiological health or environmental concern. The study therefore supporis the conclusion that no abnormal environmental hazard as a result of past Laboratory activities, exists on the surveyed parcels of land.
\end{abstract}

\section{INTRODUCTION}

At the request of the Los Alamos Area Office (LAAO), U. S. Atomic Energy Commission (USAEC), personnel of the Los Alamos Scientific Laboratory (LASL) conducted an environmental radiological evaluation on about 5,500 acres of USAEC-owned real property during June 1972. The land areas surveyed were entirely within Los Alamos County and near the boundaries of the LASL technical area. Nuclear research and development activities have been conducted at this locality since the early $1940^{\prime}$ 's as a Manhattan Dis trict Project installation and later as directed by the University of California's Los Alamos Scien- tific Laboratory under the sponsorship of the USAEC. The objective of the survey was to determine the actual, potential or proximal involvement of the designated parcels of land in the siteassociated work and to assess the environmental radiological status of this property in order that the suitability of the parcels of land for disposal by the USAEC may be established.

The land parcels surveyed and assessed are designated $A, B, C, E, K, L, N$, and $P L$ (pipeline). The general location and relative size of each land area are shown in Fig. 1. 


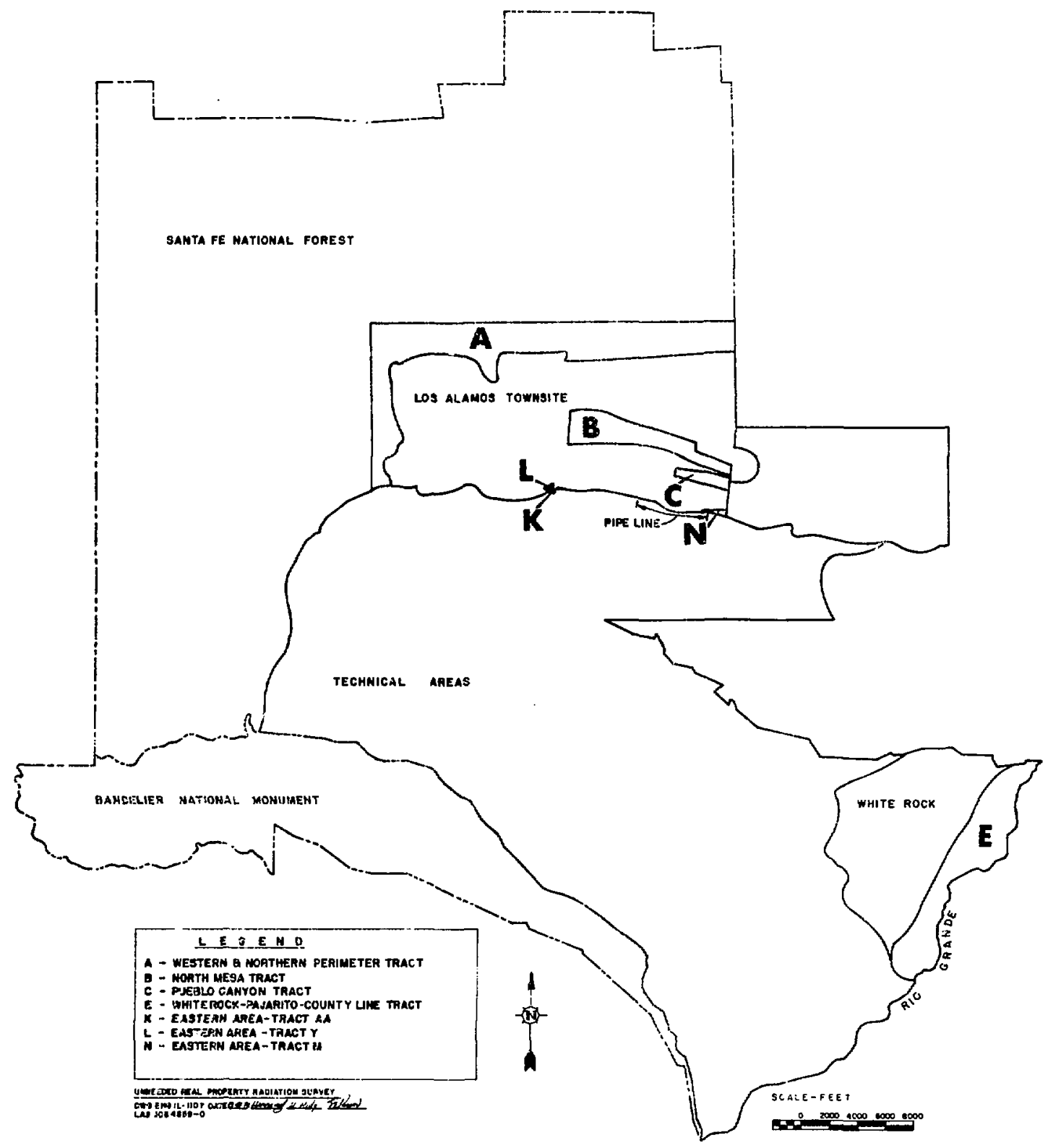

Fig. 1. Relative size and location of the Los Aiamos land areas surveyed. 


\section{PROCEDURE}

The environmental assessment of these real properties included a earch of available records to determine historical land use by the Laboratory or its predecessor, radiation measurements in the fieid, and radiochemical analysis of soil and vegetation samples. During the course of the field work, attention was also given to a search for evidence of any possible non-radioactive hazards, i. e., explosives, chemicals, etc.

The potential for radioactive material disposal or deposition as a result of Laboratory work activities in each land area was determined by a review of Laboratory documents and records. Engineering and health physics files were searched for evidence that the land might have been used for structures, experimental activities, or wastedisposal. In addition, personnel interviews were conducted with employees whose employment began in the early phases of the projers to augment and substantiate available records.

The locations established for field measurement and sample collection were defined by an engineering survey crew. Stakes were used to mark each measurement and collection point in the field. This procedure allowed secondary readings or sample acquisitions at the same location where subsequent findings might indicate this need. Each sampling point was identified on maps using the New Mexico Plane Coordinate System. The number of assessment points within each land parcel were arbitrarily predetermined, based on acreage and on a weighed judgement that a high probability existed that none of the areas were ever involved in Laboratory activities. Thus, any contamination encountered would have resulted from airborne materials emitted by adjacent Laboratory facilities with a consequent relatively uniform deposition pattern. The location of a sampling point within a land parcel was influenced principally by physical terrain features which allowed access and the availability of engineering survey markers from which the sampling poirt coordinates were determined. The coordinates of each sampling point, its location within a parcel, and the area of each parcel are shown in Figs. 2 through 6.

In addition to the measurements and collections made on the real property described above, background measurements and collections were made at points 30 to 50 air miles north, south, east, and west of Los Alamos in north central New Mexico. These points were at locations designated as Cochiti, Ponderosa, Tesuque, Santa Cruz, and Taos and were near these respective geographical sites.

The problem of documenting very low radiation levels was identified early in the study as a major cause for concern. This concern lead to discussions with personnel from USAEC Headquarters - Division of Waste Management regarding the survey instrument of choice for this type of survey, i. e., measurement of radiation in the micro-Roentgen per hour ( $\mu R / h$ ) range. As a result of these discussions, attempts were made to identify an instrument that had been used in another environmental survey. This investigation led, by way of discussions with personnel from the Oak Ridge National Laboratory and the instrument manufacturer, to the conclusion that the referenced instrument was not a stock item but rather an instrument modified in an unknown way, arid to the fact that the Environmental Protection Agency's Western Environmental Research Labcratory (EPA-WERL) was a user of the modified instrument, WERL personnel, however, indicated that, for a variety of reasons, the instrument in ques tIon had been replaced in their work by the Ludlum Model.12S Count Rate Meter. This instrument is specially assembled by Ludlum and is not a stock item. Two of the instruments were purchased and calibrated for the survey.

The Ludlum Model 12S Count Rate Meter, which utilizes a $\mathrm{NaI}(\mathrm{Tl})$ scintillation detector, was used for in situ environmental radiation measure- 


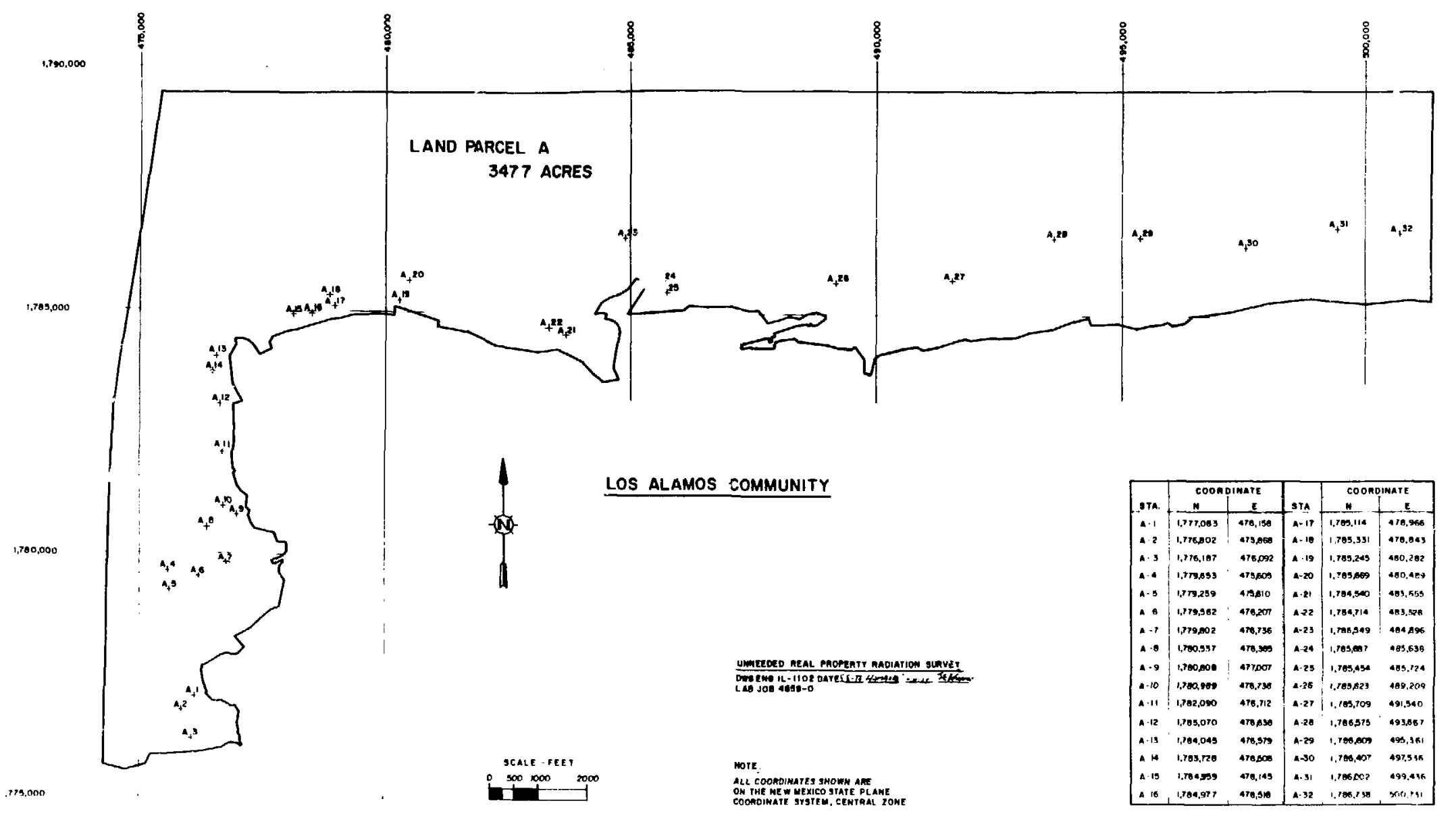

Fig. 2. Land parcel "A" measurement and sampling points, coordinates, and acreage. 


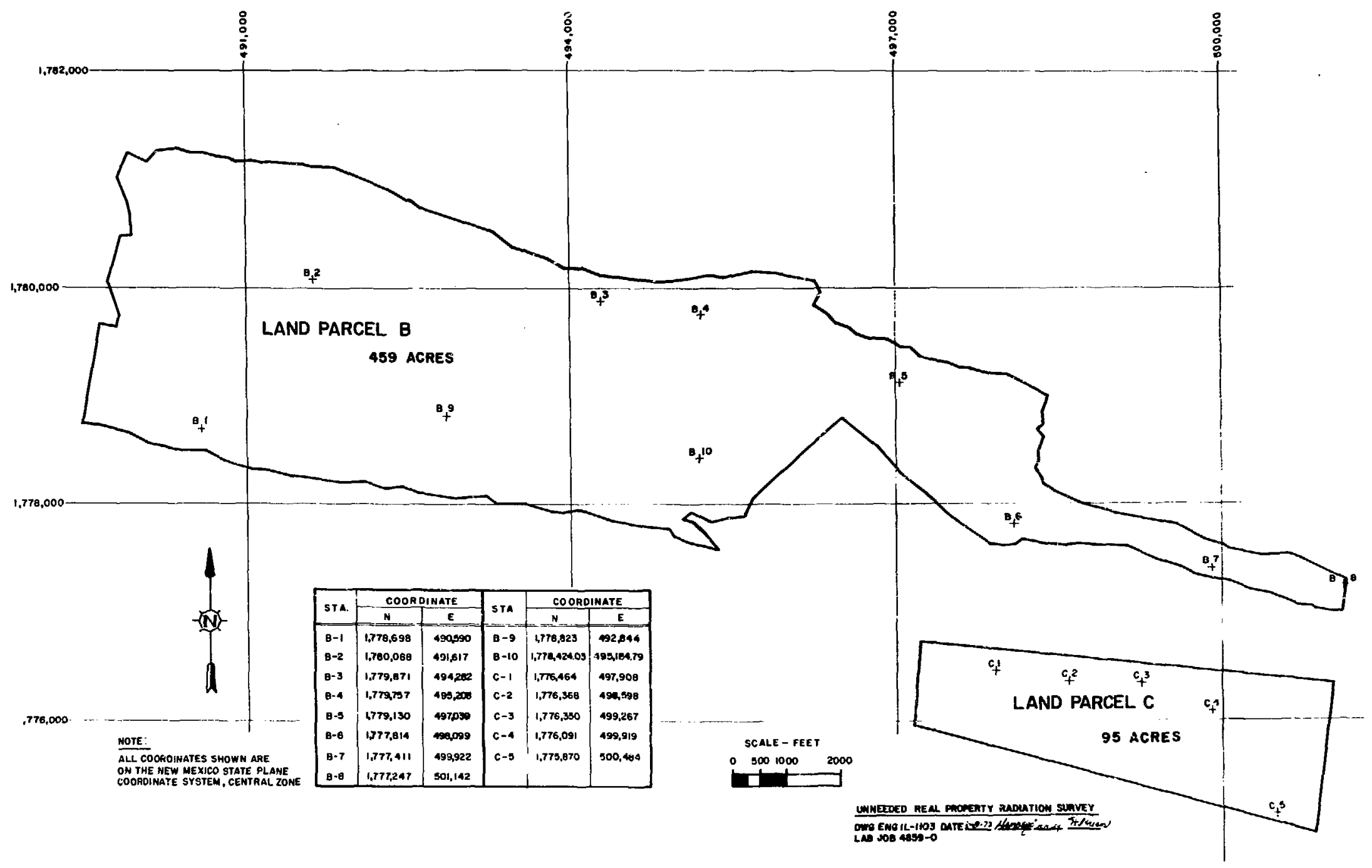

Fig. 3. Land parcels "B" and "C" measurement and sampling points, coordinates, and acreage. 


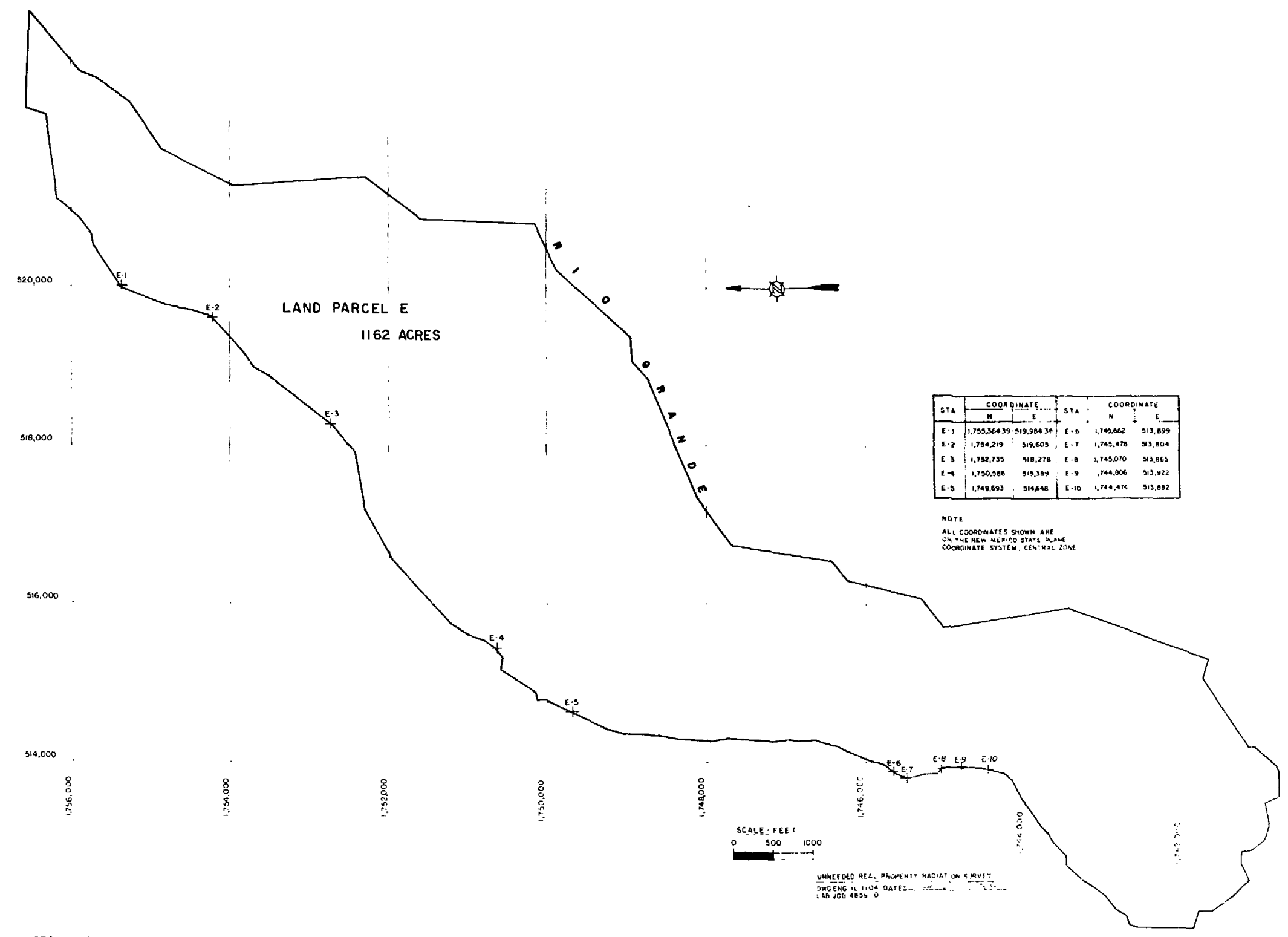

Fig. 4. Land parcel "E" measurement and sampling points, coordinates, and acreage. 


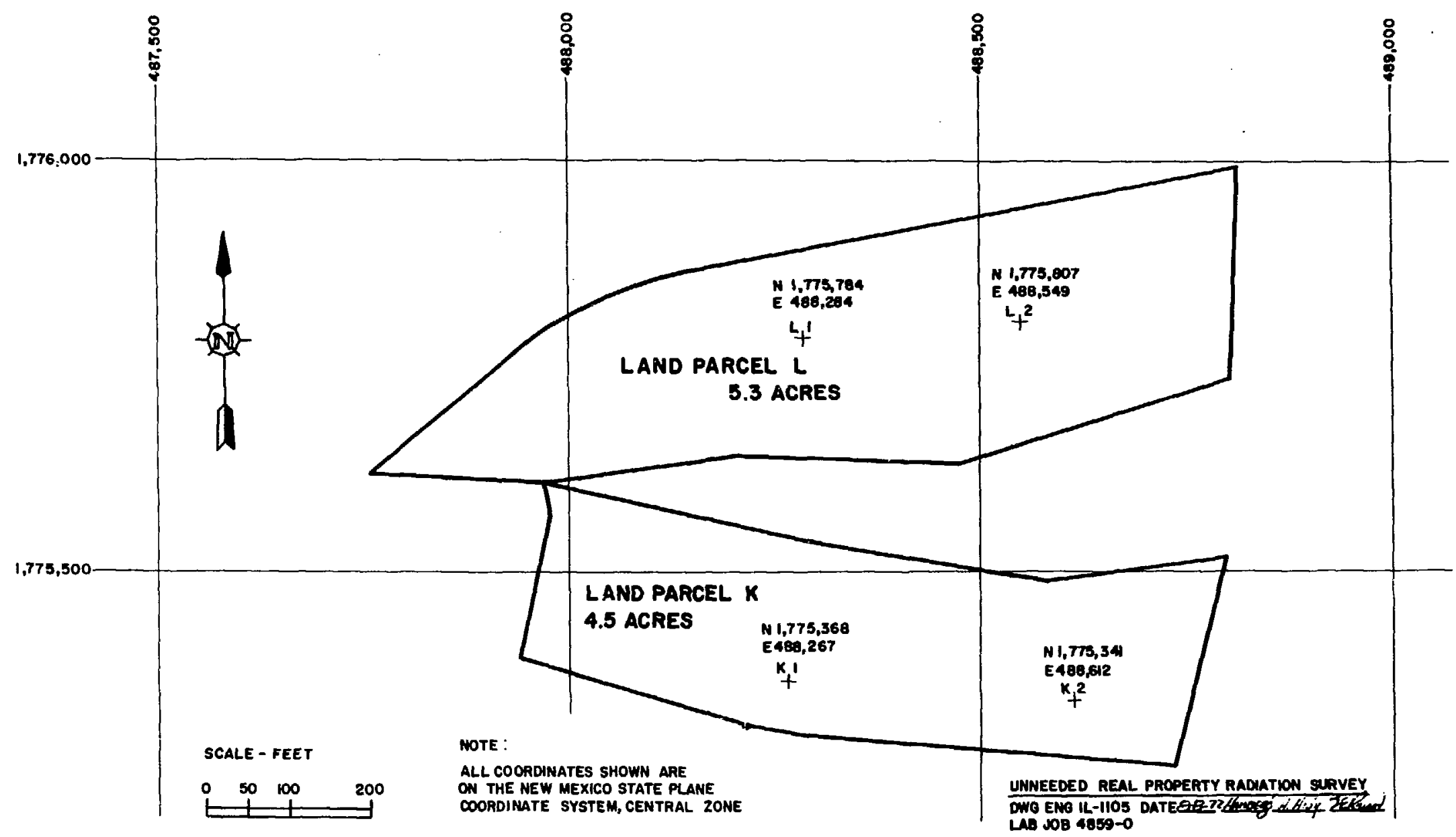

Fig. 5. Land parcels " $K$ " and " $L$ " measurement and sampling points, coordinates, and acreage. 
$\infty$

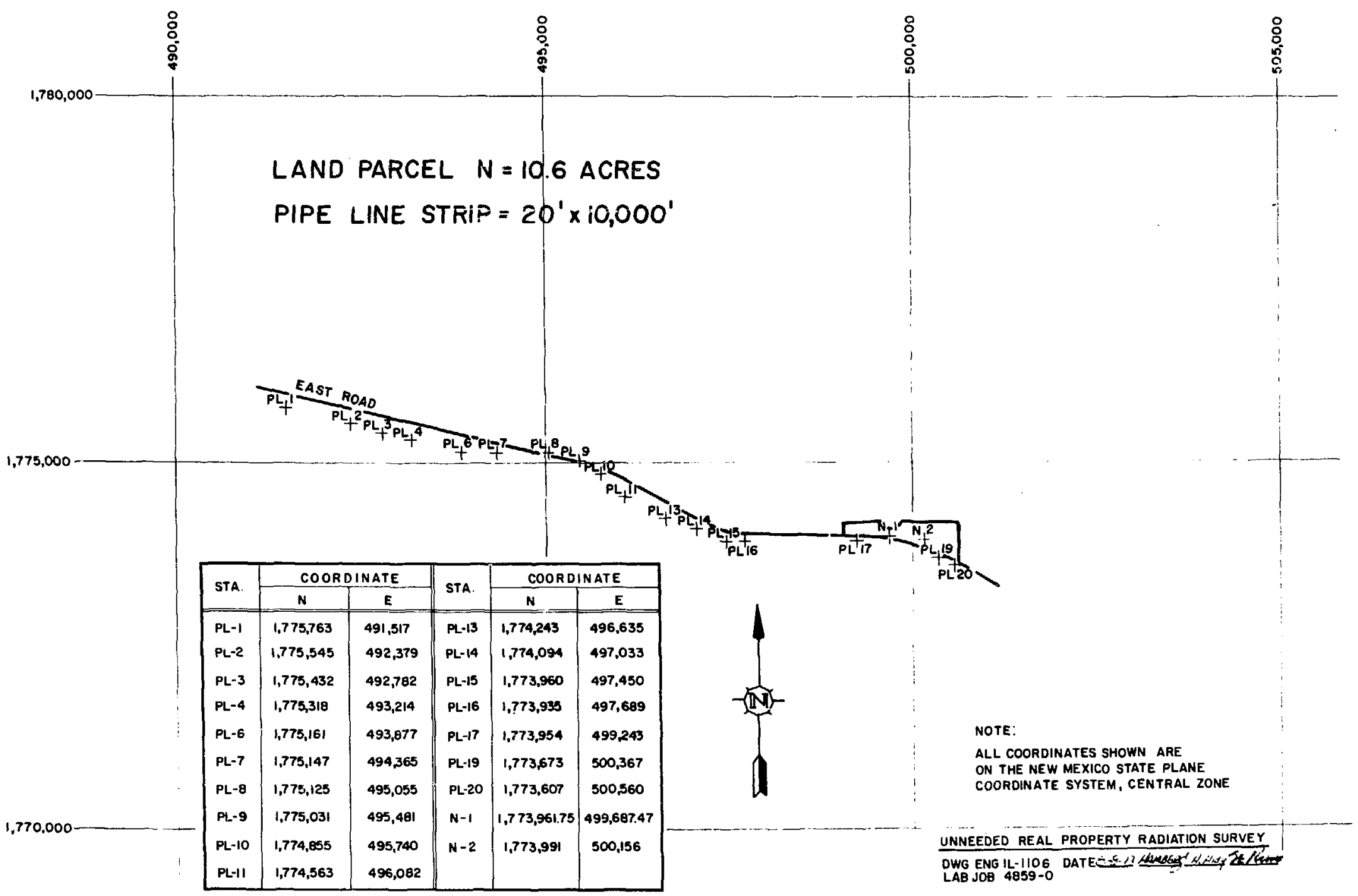

Fig. 6. Land parcel " $\mathrm{N}$ " and the gas pipeline strip measurement and sampling points, coordinates, and acreage. 
ments. This instrument's readout is indicated in " $\mu R / h$ " and was calibrated to give a proper reading with ${ }^{60}$ Co gamma rays. During the survey, the instrument was held at about $3-\mathrm{ft}$ above the ground surface and the observed rate noted and recorded at the respective locations.

The response of the instrument as a function of photon energy was determined using monoenergetic $x$-ray and gamma-ray sources in the laboratory ${ }^{1}$ and is shown in Fig. 7. Because of the inherent photon energy-dependent response, all readings obtained were normalized using 10 LASL environmental radiation dosimetry stations whichutilize LiF thermoluminescent dosimeters (TLD) for background radiation measurements. ${ }^{2,3}$ Dosimetric values obtained from these TLD materials have been' shown to be essentially independent of radiation energy and, therefore, provided a basis for the correction or normalization of the Ludlum Model 125 meter readings. The normalization assumed uniform photon spectral distribution. The observed average ratio of TLD-determined exposure rates to the survey meter measurements was 0,70 .

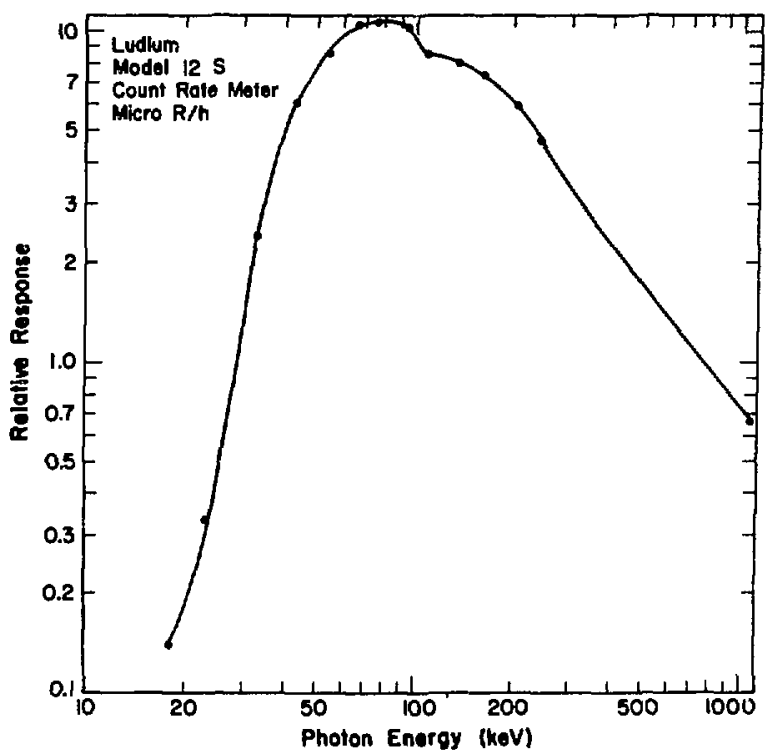

Fig. 7. Experimentally determined response curve of the Ludlum Model 12S Count Rate Meter detector as a function of photon energy.

\section{Because of the LASL's past heavy metals} research and development activities, measurement of environmental plutonium, americium, etc., was important. The principle emissions of these materials are alpha and low energy $x$ rays or gamma rays. Measurement of alpha radiation with the emitters in environmental media such as soil or vegetation is difficult and lacking in needed sensitivity. The low energy photon emissions of the heavy metal materials are not efficiently detected by the " $\mu R / h$ " survey meter as discussed above. The need for a system to provide field measurements for determining environmental levels of materials like plutonium resulied in an instrument design and development effort. The Los Alamos Field Pulse Height Analyzer (LAFPHA) described below was developed to aid in this project by the joint efforts of LASL Groups E-4 and $\mathrm{H}-8$.

The second detection system utilized for field radiation measurements for gross indications of plutonium and americium contamination was the Los Alamos Field Pulse Height Analyzer (LAFPHA). The detector used was the Field Instrument for the Detection of Low Energy Radiation (FIDLER). The detector is $1 / 16-\mathrm{in}$, thick by 5-in. diam $\mathrm{NaI}(\mathrm{T} 1)$ scintillation counter mounted with a 0.010-in. beryllium entrance window. The signal from this detector is received by the LAFPHA for sorting and counting. The LAFPHA's principle features are six individually settable windows or channels, a preset count time selection capability, a scaler for recording the number of individual pulses sensed, manually selectable and visually displayed count readout for each of the six channels, a count rate meter, an audio signal output, and several other operational features described in Ref. 4. The instrument is pictured in Fig. 8. In the present application, Channels 1 through 6 were set with respective energy bounds of: 4 to 10,10 to 23,23 to 34,34 to 46 , 46 to 68 , and 68 to $84 \mathrm{keV}$. Channel 2 was set to 


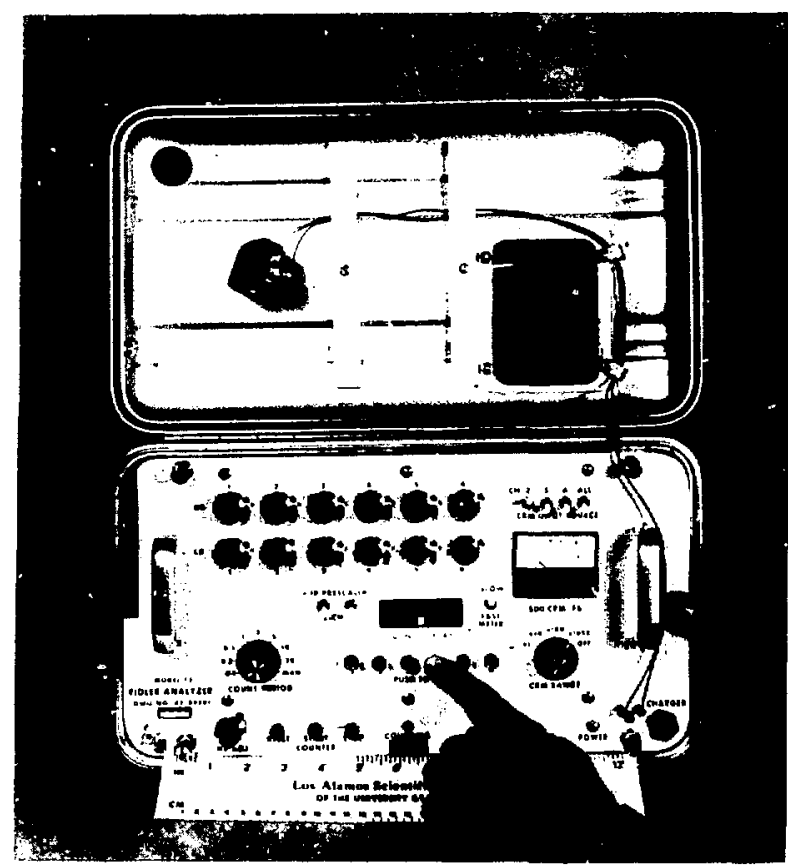

Fig. 8. The Los Alamos Field Pulse Height Analyzer (LAFPIA) front panel instrumentation controls.

detect the L-series $x$ rays of uranium which occur following the alpha decay of plutonium and have an effective energy of about $17 \mathrm{keV}$ and channel 5 was adjusted to detect the $59.5 \mathrm{keV}$ gamma ray emis sion of ${ }^{241}$ Am which is commonly associated with plutonium.

This detection system was calibrated to measure the presence of the $\mathrm{e}$ radionuclides principally on or near the ground's surface. All measurements were taken during June because the ground was dry. The presence of moisture would inter fere with the detection of low energy photons. The detector was positioned in a tripod 12-in. above the earth's surface, as depicted in Fig. 9. Measurement times of 20-min were selected on the LAFPHA for each measurement which proceeded as other measurements and collections weremadc.

Soil and vegetation samples were collected at each designated sampling point for radiochemical analyses. The soil samples consisted of a

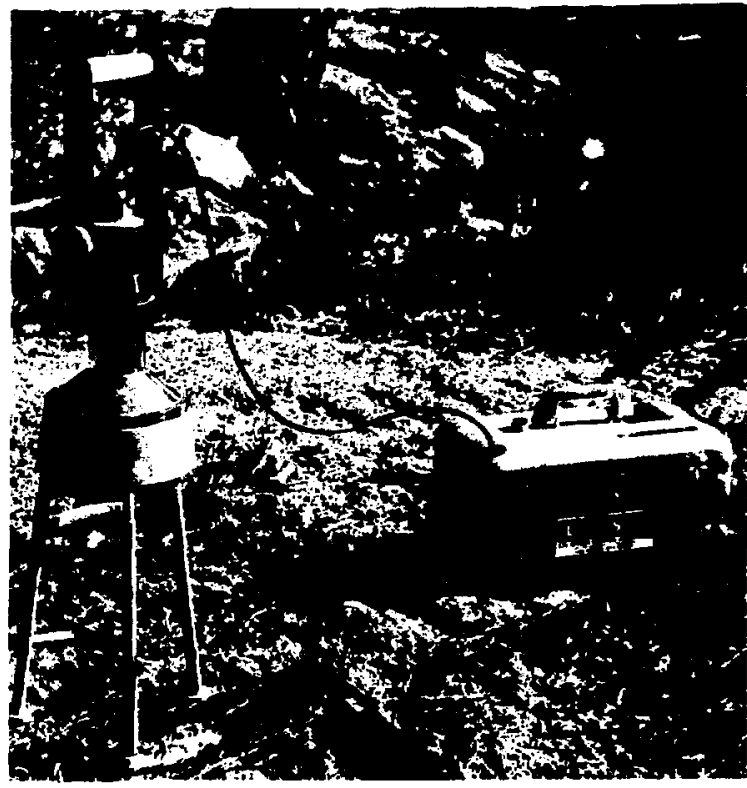

Fig. 9. Field setup of the FIDLER detector and the LAFPHA readout system.

3-in. diam by 2-in. deep core sample at the center and corners of a 33-ft square. These soil cores were composited to form a single soil sample representing a point within a land area. Ponderosa, piñon, and juniper needles were collected and analyzed. These predominate tree species were selected because they are perennial and may have adsorbed any airborne contaminants released. Activity concentration determinations were made on soil and plant samples for:

1. Tritium (in the free moisture of plant tissues)

2. Gross beta emitters

3. Cesium-137

4. Plutonium-238, 239

5. Americium-241

6. Uranium (total)

Water from the vegetation samples was collected by a distillation technique. Four milliliters of the sample moisture were analyzed for tritium content by liquid scintillation counting. Following collection of the vegetation moisture, for tritium assay, each sample (sample mass 
varied from 100 to about $400 \mathrm{~g}$ ) was dry ashed at $500^{\circ} \mathrm{C}$, dissolved in nitric acid, wet ashed with hydrogen peroxide, treated with hydrofluoric acid to dissolve any silicious residue and diluted to $500 \mathrm{ml}$ for analysis.

The soil samples were manually blended in the plastic collection containers and $100 \mathrm{~g}$ aliquots of each were dry ashed at $500^{\circ} \mathrm{C}$ and leached with zitric and hydrofluoric acids. The filtered leachates were diluted to $500 \mathrm{ml}$ for analysis. A complete library of individual vegetation and soil sam. ples is presently available for potential use in replicate or special analyses.

Gross beta activities were determined by evaporating a $10 \mathrm{ml}$ aliquot of the leached or dissolved sample on a stainless steel planchet and counting with a gas flow proportional counter. Cesium- 137 activities were determined by direct gamma spectrometry on the dissolved sample with a NaI(T1) scintillation detector system. Plutonium and americium concentrations were measured in a $50 \mathrm{ml}$ aliquot of the sample by isolation of the elements on ion exchange columns, electrodeposition and alpha spectrometry. Total uranium concentretions were measured by extracting the uranium from a $10 \mathrm{ml}$ aliquot of the leached or dissolved sample with ethyl acetate and measuring the fluoresence in a lithium fluoride matrix. Some sample solutions were composited, within land parcel sets, at the ion exchange step for actinide content determinations. Sample compositing within a given land area expedited completion of the analyses. The compositing procedure was judged to be technically feasible because of the uniform nature of any potential contaminant present as discussed above.

\section{RESULTS}

A complete listing of individual and composite measurements and analyses are given in the Appendix Tables. The " \pm " values listed are single standard deviations due to counting statistics.
Composite sample results are listed in the Tables of the Appendix with identification notation ending with "C", e.g., E-1C.

No potential non-radioactive environmental hazards were observed during the course of this survey.

A. Record Search

A LASL records search together with personnel interviews did not reveal any indication of disposal, burial, or storage of radioactive materials on the real properties surveyed. The extent of the review and the findings are described in the Jordan/Meyer Memorandum as shown in Fig. A-1 on the last page of the Appendix.

\section{B. Field Survey}

The results of the gross gamma field radiation measurements are summarized in Table $I$. The exposure rates are those corrected in accor. dance with the procedure previously described. The background measurements obtained in northern New Mexico fluctuated over a wide range. The average gross gamma radiation measurements obtained on the designated land parcels were not significantly different from the measurements obtained at remote locations or what could be considered to be the natural background radiation levels for this north central New Mexico area. Measured values of radiation on the land parcels also fell within the range of $13-21 \mu \mathrm{R} / \mathrm{h}$ suggested by Cowan ${ }^{5}$ as being normal for the Los Alamos elevation depending on the geological composition of the earth's crust.

TABLE I

GROSS GAMMA FLELD RADIATION MEASUREMENTS

\begin{tabular}{lcc} 
Location & Range, $\mu R / h$ & Average, $\mu R / h$ \\
\cline { 2 - 3 } Northern & & 15.1 \\
New Mexico & $11-20$ & 18.1 \\
Parcel A & $16-25$ & 17.6 \\
Parcel B & $16-19$ & 21.8 \\
Parcel C & $19-27$ & 10.9 \\
Parcel E & $8-13$ & 16. \\
Parcel K & 16 & 17.2 \\
Parcel I & $17-18$ & 14. \\
Parcel N & 14 & 16.2 \\
Parcel PL & $14-19$ &
\end{tabular}


TABLE II

MEAN RATIOS AND 95\% CONFIDENCE INTERVALS *

\begin{tabular}{|c|c|c|c|c|}
\hline \multirow[b]{2}{*}{ Parcel } & \multicolumn{2}{|c|}{ Channel 2/Channel I } & \multicolumn{2}{|c|}{ Channel $2 /$ Channe 13} \\
\hline & Range & Average & Range & Average \\
\hline Bkgd & $0.61-1.03$ & 0.82 & $0.85-1.16$ & 1.01 \\
\hline $\mathbf{A}$ & $0.71-1.07$ & 0.89 & $0.89-1.13$ & 1.01 \\
\hline B & $0.87-1.01$ & 0.94 & $0.98-1.09$ & 1.04 \\
\hline c & $0.99-1.13$ & 1.06 & $0.99-1.05$ & 1.02 \\
\hline $\mathbf{E}$ & $0.56-0.82$ & 0.69 & $0.17-1.33$ & 0.75 \\
\hline $\mathbf{K}$ & $0.75-0.97$ & 0.86 & $0.92-1.20$ & 1.06 \\
\hline $\mathbf{L}$ & $0.87-0.97$ & 0.92 & $1.08-1.10$ & 1.09 \\
\hline $\mathbf{N}$ & $0.78-0.92$ & 0.85 & $0.98-1.04$ & 1.01 \\
\hline PL & $0.76-0.96$ & 0.86 & $0.94-1.10$ & 1.02 \\
\hline
\end{tabular}

\begin{tabular}{ll}
$\frac{\text { Channel 2/Chaniel } 6}{\text { Range }}$ & Average \\
\hline $0.15-0.24$ & 0.19 \\
$0.16-0.20$ & 0.18 \\
$0.17-0.19$ & 0.18 \\
$0.16-0.18$ & 0.17 \\
$0.20-0.24$ & 0.22 \\
$0.17-0.19$ & 0.18 \\
$0.17-0.19$ & 0.18 \\
$0.17-0.19$ & 0.18 \\
$0.16-0.18$ & 0.17
\end{tabular}

\begin{tabular}{ll}
\multicolumn{2}{c}{ Channel $5 /$ Channel 4} \\
\hline Range & Average \\
\hline $2.60-4.48$ & 3.54 \\
$3.64-4.24$ & 3.94 \\
$3.59-3.99$ & 3.79 \\
$3.77-3.99$ & 3.88 \\
$3.20-3.90$ & 3.55 \\
$3.93-3.99$ & 3.96 \\
$3.68-3.96$ & 3.82 \\
$3.86-3.88$ & 3.87 \\
$3.72-4.06$ & 3.89
\end{tabular}

${ }^{a}$ Column heading whow average channel seading ration for each parcel and the $95 \%$ confidence interval for the reepective average value.

The gross count rates observed in each of: the LAFPHA's six channels are recorded in Tabie A-II. Ratios of the observed count rates in channels 2 and 5 , the channels into which photons of 17 and $59.5 \mathrm{keV}$ regions would fall, to surrounding channels were computed for each measurement point and appear in Table A-III. A summary of these ratios is shown in Table II. No statistically significant differences were observed at the $5 \%$ error level with the exception of Area $E$ where lower ratios were observed (opposite of that expected where plutonium or americium are present). This anomally may be due to counting geometry circumstances discussed below.

Radioactive contamination was not identifiable above the natural radiation levels by use of field instrumentation. It was observed that some of the count rate variation, both the extreme low and high rates, derived from the counting geometry at the respective measurement locations. High count rates were observed where the measurement point was at the convergence of two or more slopes (in a valley or gully) or vertical protrusions making the effective surface area larger and, therefore, the observed count rate higher. Low values, such as some of those observed in Area $E$, occurred because the measurement point was near the edge of a mesa providing a reduced land surface area and, therefore, a lower overall geometry.

\section{Laboratory Sample Analyses}

The results of the tritium determinations on plant water are summarized in Table III. Compared to the beckground samples, the tritium in vegetation appears to be measureably higher on the land parcels surveyed. This finding is consistent with that reported 2,3 for the tritium activity measured in the atmospheric water near the Laboratory where the tritium concentration appears to be about twice the values observed at locations distant from the Laboratory. The average tritium concentration measured in these parcels is within the range of the values 10.2 to $6.4 \mathrm{pCi} /$ ml) reported for vegetation in the Livermore Valley. 5 While standards for the tritium concentration in the moisture of vegetation have not been established, it is useful, as a frame of reference, to compare the observed concentrations with concentration guides listed in USAEC Manual Chapter 0524 for tritium in water in uncontrolled areas.

TABLE III TRITIUM IN VEGETATION

$\begin{array}{lcc}\text { Location } & \text { Range, } \mathrm{pCi} / \mathrm{ml} & \text { Average, PCi/ml } \\ \text { Northern } & <1.0 & <1.0 \\ \text { New Mexico } & <1.0-5.8 & <2.8 \\ \text { Parcel A } & 1.1-3.7 & 2.5 \\ \text { Parcel B } & 1.3-2.8 & 1.7 \\ \text { Parcel C } & <1.0-8.0 & <3.0 \\ \text { Parcel E } & 4.6-5.8 & 5.2 \\ \text { Parcel K } & 5.6-5.8 & 5.7 \\ \text { Parcel L } & 4.7 & 4.7 \\ \text { Parcel N } & <1.0-9.6 & 4.1 \\ \text { Parcel PL } & & \end{array}$


TAHLE IV

GROSS BETA ACTIVITY IN VEGETATION AND SOIL
Location

Northern

New Mexico

Parcel A

Parcel B

Parcel C

Parcel E

Parcel K

Parcel L

Parcel N

Parcel PL

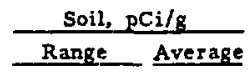

$\begin{array}{cc}16.2-31.7 & 21.4 \\ 13.1-31.6 & 23.8 \\ 20.0-26.3 & 22.8 \\ 20.9-26.9 & 24.2 \\ 13.4-19.7 & 15.3 \\ 16.4-21.5 & 19.0 \\ 16.6-26.5 & 21.6 \\ 37.6 & 37.6 \\ 17.4-26.4 & 21.2\end{array}$

Vegetation, pCH/g Range Averare

$4.2-5.14 .6$

$2.1-6.0 \quad 4.5$

$4.4-6.05 .3$

$3.7-6.75 .0$

$3.5=13.45 .4$

$2.7=6.24 .5$

$3.8=\quad \therefore .7 \quad 4.3$

$3.2=15.7 \quad 9.5$

$0.3-22.7 \quad 9.6$
This guide is $3 \times 10^{-3} \mu \mathrm{Ci} / \mathrm{ml}$. The values measured are about 0.1 percent of this value.

The observed gross beta concentrations in vegetation and soil and the summary tabulations of the ${ }^{137} \mathrm{Cs}$ activity concentrations in vegetation and soil are shown in Tables IV and V. The average ${ }^{137} \mathrm{Cs}$ values measured on the land parcels surveyed appear to be about equal to the background values for north central New Mexico. No large deviations from the average levels of ${ }^{137} \mathrm{Cs}$ were observed in either vegetation or soil samples. The gross beta activities of samples obtained from surveyed land parcels do not appear to be different from the samples obtained from remote areas. The single soil sample analyzed for Area $\mathrm{N}$ was somewhat higher than the average values observed for other areas. The higher gross beta activity reported for some vegetation samples is maybe due to the inclusion of a variable amount of associated soil.

Summary plutonium concentration values in vegetation samples are shown in Table VI. The average ${ }^{238} \mathrm{Pu}$ concentrations were not statistically significantly different due to the relatively large average standard deviation for these measurements. The chemical recovery values ranged from 10 to 80 percent which contributed to the relatively large standard deviations. The average concentration (wet weight) of ${ }^{23}{ }^{9} \mathrm{Pu}$ for samples obtained from Parcels E and PL were significantly above worldwide fallout levels as indicated by the background samples obtained in north central New Mexico. An unknown amount of soil adsorbing to the plant samples may have accounted for the elevated concentrations observed. Plutonium activities in vegetation at points greater than 5 miles from the Rocky Flats Plant ranged from 0.036 to $0.045 \mathrm{pCi} / \mathrm{g}$ of vegetation dried at $120^{\circ} \mathrm{F}^{\gamma}$ Assuming an 80-90\% plant moisture content, the reported concentrations are comparable to those obeerved here.

The plutcriium values measured in soil are summarized in Table VIl for both the surveyed and the background areas. Individual samples ranged in activity up to an order of magnitude larger than the average background values measured. Due to the large uncertainty values associated with the Area $C$ and $E$ measurements, these numbers are not statistically different from zero at the $5 \%$ error level. Airborne effluent from a laboratory research facility near the pipeline strip appears to have elevated the soil's plutonium concentration in this area by an average factor of 2 to 3 over worldwide fallout levels. The average plutonium concentration values for the other land areas surveyed do not appear to be significantly different from the observed background measurements nor from reported plutonium in soil concentrations due principally to worldwide fallout. ${ }^{6,8}$ The values reported in the foregoing references range from 0.001 to 0.20 $\mathrm{pCi} / \mathrm{g}$.

TABLE $V$

337 CS DN YEGETATION AND SOLL

\begin{tabular}{lccc} 
& \multicolumn{2}{c}{ Soil, PCi/g } \\
$\begin{array}{l}\text { Location } \\
\text { Northern }\end{array}$ & Range & Average \\
New Mexico & $1.2-5.7$ & 3.6 \\
Parcel A & $0.9-9.2$ & 4.0 \\
Parcel B & $1.9-4.0$ & 2.9 \\
Parcel C & $2.4-3.6$ & 3.0 \\
Parcel E & $0.9-2.1$ & 1.6 \\
Parcel K & $2.3-3.5$ & 2.9 \\
Parcel L & $3.1-3.9$ & 3.5 \\
Parcel N & 1.6 & 1.6 \\
Parcel PL & $1.1-4.3$ & 2.5
\end{tabular}

\begin{tabular}{lc}
\multicolumn{2}{c}{ Vegetation, $\mathrm{pCi} / \mathrm{g}$} \\
\cline { 1 - 1 } Range & Average \\
\cline { 1 - 1 } $0.5-2.4$ & 1.6 \\
$0.5-6.7$ & 1.4 \\
$0.5-6.1$ & 2.2 \\
$0.5-3.0$ & 1.3 \\
$0.5-1.7$ & 1.2 \\
$0.3-6.4$ & 3.3 \\
$0.7-1.5$ & 1.1 \\
$3.7-9.8$ & 6.7 \\
$0.1-5.6$ & 2.3
\end{tabular}


TABLE VI

PLUTONIUM IN VEGETATION

\begin{tabular}{|c|c|c|}
\hline \multirow[b]{2}{*}{ Location } & \multicolumn{2}{|c|}{${ }^{3}{ }^{3} \mathrm{Pu}, \mathrm{pCi} / \mathrm{g}$} \\
\hline & Range & Average \\
\hline $\begin{array}{l}\text { Northern } \\
\text { New Mexica }\end{array}$ & $0.002-0.005$ & 0.004 \\
\hline Parcel A & $<0.001 \cdot 0.004$ & 0.002 \\
\hline Parcel B & $0.005-0.007$ & 0.006 \\
\hline Parcel C & $<0.001$ & $<0.001$ \\
\hline Parcel E & $0.003-0.03$ & 0.016 \\
\hline Parce! K & 0.002 & 0.002 \\
\hline Parcel L & $<0.001$ & $<0.001$ \\
\hline Parcel N & 0.001 & 0.001 \\
\hline Parcel PL & $<0.001-0.005$ & 0.003 \\
\hline
\end{tabular}

The range and average $241 \mathrm{Am}$ concentrations observed in the samples collected on the land parcels and from localities in north central New Mexico are listed in Table VIII. The observed chemical recovery values ranged from 10 to 80 percent for the americium analyses. The measured con. centration of ${ }^{241} \mathrm{Am}$ for samples obtained from the land parcels appear to be identical to values from background areas with the exception of the vegetation samples in the PL Area. No reports of background values for americium in soil or vegetation were available in the literature for comparison with our measured values.

A summary of the measurements of the uranium concentration in soil and vegetation samples is shown in Table IX. Values of 0.03 to $3.0 \mu \mathrm{g} / \mathrm{g}$ in soil and 0.1 to $20 \mu \mathrm{g} / \mathrm{g}$ of vegetation have been reported $2,3,5,9$ at locations remote from nuclear facilities. The observed values fall within these reported ranges.

TABLE VUI

AMERICIUM IN SOIL AND VEGETATION

\begin{tabular}{|c|c|c|c|c|}
\hline \multirow[b]{2}{*}{ Location } & \multicolumn{2}{|c|}{ Soil $21 \mathrm{Am}, \mathrm{pCi} / \mathrm{g}$} & \multicolumn{2}{|c|}{ Vegetation $21 \mathrm{Am}, \mathrm{pCi} / \mathrm{g}$} \\
\hline & Range & Average & Range & Average \\
\hline $\begin{array}{l}\text { Northern } \\
\text { New Mexico }\end{array}$ & $0.03-0.09$ & 0.06 & $0.003-0.012$ & 0.007 \\
\hline Parcel A & $<0.01-0.90$ & $<0.04$ & $0.004-0.14$ & 0.016 \\
\hline Parcel B & $0.01-0.14$ & 0.10 & $0.006-0.012$ & 0.009 \\
\hline Parcel C & 0.05 & 0.05 & 0.004 & 0.004 \\
\hline Parcel E & $<0.01-0.08$ & $<0.03$ & $0.007-0.029$ & 0.018 \\
\hline Parcel K & 0.03 & 0.03 & 0.006 & 0.006 \\
\hline Parcel L & 0.04 & 0.04 & 0.006 & 0.006 \\
\hline Parcel N & 0.03 & 0.03 & 0.016 & 0.016 \\
\hline Parcel PL & $<0.01-0.07$ & $<0.04$ & $0.010-0.057$ & 0.034 \\
\hline
\end{tabular}

TABLE VII

PLUTONIUM IN SOIL

\begin{tabular}{|c|c|}
\hline Range & Average \\
\hline 0.0$\rfloor-0.50$ & 0.13 \\
\hline $0.01-0.6$ & $<0.17$ \\
\hline $0.01-0.2$ & $<0.11$ \\
\hline 0.30 & 0.30 \\
\hline $0.01-1.2$ & 0.49 \\
\hline 0.05 & 0.05 \\
\hline 0.01 & 0.01 \\
\hline 0.01 & 0.007 \\
\hline $0.01-0.05$ & 0.02 \\
\hline
\end{tabular}

\begin{tabular}{cc}
\multicolumn{2}{c}{${ }^{239} \mathrm{Pu}, \mathrm{PC} / \mathrm{g}$} \\
\hline $0.02-0.11$ & 0.048 \\
$0.01-0.22$ & 0.08 \\
$0.01-0.08$ & 0.05 \\
0.12 & 0.12 \\
$<0.01-1.0$ & 0.44 \\
0.02 & 0.02 \\
0.04 & 0.04 \\
0.04 & 0.04 \\
$0.04-0.39$ & 0.12
\end{tabular}

Location
Northern
New Mexico
Parcel A
Parcel B
Parcel C
Parcel E
Parcel K
Parcel L
Parcel N
Parcel PL

\section{CONCLUSIONS}

The results of the radiation survey indicate that only low radiation levels are associated with the land parcels included in this study. No abnornial in situ field radiation measurements were observed in total gamma radiation measurements or from readings for low energy photons obtained with the newly developed Los Alamos Field Pulse Height Analyzer. Measurements of gross beta, $137 \mathrm{Cs}, 238,23{ }^{7} \mathrm{Pu},{ }^{241} \mathrm{Am}$ and total uranium in soil and vegetation samples obtained on the land areas monitored indicate, in general, concentrations similar to those measured at locations undisturbed by nuclear energy installations. Tritium concentrations in general and $\mathrm{Pu}$ and Am concentrations at a few points appeared to be above that expected from past weapons testing fallout.

\section{T.ABLE IX}

URANIUM IN SOIL AND VEGETATION

\begin{tabular}{|c|c|c|c|c|}
\hline \multirow{2}{*}{$\begin{array}{l}\text { Location } \\
\text { Northern } \\
\text { New Mexico }\end{array}$} & \multicolumn{2}{|c|}{$\begin{array}{c}\text { Total } U \text { in Soil, ug/g } \\
\text { Range Average }\end{array}$} & \multicolumn{2}{|c|}{$\frac{\text { Total } U \text { in Vegetation, } \mu g / g}{\text { Range }}$} \\
\hline & $0.16-1.24$ & 0.58 & $<0.02-0.05$ & $<0.03$ \\
\hline Parcel A & $0.28-1.50$ & 0.83 & $0.04-0.27$ & 0.10 \\
\hline Parcel B & $0.71 \cdot 1.13$ & 0.92 & $0.10-0.12$ & 0.11 \\
\hline Parcel C & 0.65 & 0.65 & 0.07 & 0.07 \\
\hline Parcel E & $0.39-0.65$ & 0.49 & $0.04-0.38$ & 0.21 \\
\hline Parcel K & 0.65 & 0.65 & 0.02 & 0.02 \\
\hline Parcel L & 0.60 & 0.60 & 0.07 & 0.07 \\
\hline Parcel N & 0.75 & 0.75 & 0.15 & 0.15 \\
\hline Parcel PL & $0.37-0.56$ & 0.42 & $0.05-0.20$ & 0.12 \\
\hline
\end{tabular}


All results generated by this study confirm and are in substantial agreement with the generally low levels of radiation and radioactive contaminants in the Los Alamos environs noted in the reports of the LASL environmental surveillance program. ${ }^{2}, 3$ No environmental standards exist for radionuclides in soil or vegetation and therefore the measured values have been compared to reported worldwide levels. No radiation or radiocontamination observations were encountered which are of radiological or environmental concern. As a result of this study, therefore, it is reasonable to conclude that no abnormal environmental hazards exist on the designated parcels of land.

\section{ACKNOWLEDGMENTS}

Assistance, suggestions, and contributions in the accomplishment of this survey from the following persons made its completion possible.

\begin{tabular}{|c|c|}
\hline Group H-1: & $\begin{array}{l}\text { Dean D. Meyer } \\
\text { Charles D. Blackwell } \\
\text { Donald R. Gibbons }\end{array}$ \\
\hline Group Eng-3: & $\begin{array}{l}\text { S. E. Russo } \\
\text { Donald W. Parker } \\
\text { Harold A. Hidy } \\
\text { Gary E. Hamberg }\end{array}$ \\
\hline Group H- 8: & $\begin{array}{l}\text { Harry S. Jordan } \\
\text { Thomas E. Hakonson } \\
\text { Stewart M. Lombard } \\
\text { Joseph E. Herceg } \\
\text { Pablo O. Romero } \\
\text { Jack W. Aeby } \\
\text { William H. Schweitzer } \\
\text { James W. Owens } \\
\text { E. Frank Montoya }\end{array}$ \\
\hline
\end{tabular}

\section{REFER ENCES}

1. E. Storm, Private Communication, Los Alamos Scientific Laboratory, Los Alamos, New Mexico (1972).

2. J. E. Herceg, "Environmental Monitoring in the Vicinity of the Los Alamos Scientific Laboratory," Los Alamos Scientific Laboratory report LA-4871-MS (1972).

3. J. E. Herceg, "Environmental Monitoring in the Vicinity of the Los Alamos Scientific Laboratory," Los Alamos Scientific Laboratory report LA-4970 (1972).

4. R. D. Hiebert, A. R. Koelle, and L. J. Johnson, "Development and Use of the Los Alamos Field Pulse Height Analyzer (LAFPHA),"Los Alames Scientific Laboratory report (manuscript in preparation).

5. F. P. Cowan, "Natural Radiation Background, " in Radiation Hygiene Handbook, (McGraw-Hill Book Co., New York, 1959), pp. 4-8.

6. P. H. Gudikson, C. L. Lindeken, C. Gatrousis, and L. R. Anspaugh, "Environmental Levels of Radioactivity in the Vicinity of the Lawrence Livermore Laboratory, January through December 1971, " Lawrence Livermore Laboratory report UCRL 51242 (1972).

7. M. R. Boss, Private Communication, Rocky Flats Plant, Golden, Colorado (1972).

8. P. W. Krey and E. P. Hardy, "Plutonium in Soil Around the Rocky Flats Plant," USAEC Health and Safety Laboratory report HASL-235 (1970).

9. A. I. Baeva and A. B. Akhundora, "Uranium Content in Various Types of Plants in the Subtropical Lenkorian Region of Azerbaid zhan SSR," Dokl. , Akad., Nank Azert. , SSR, 26, No. 5, pp. 69-70 (1970). (Reference in Russian, data from Nuclear Science Abstracts 25:21574). 


\section{APPENDIX}

TABLE A-I

GROSS GAMMA FIELD RADLATION MEASUREMENTS

Ludlum Model 12S NaI(Tl) Survey Meter

\begin{tabular}{|c|c|c|c|c|c|c|c|}
\hline $\begin{array}{c}\text { Survey } \\
\text { Point } \\
\end{array}$ & $u R / h$ & $\begin{array}{c}\text { Survey } \\
\text { Point } \\
\end{array}$ & $\underline{u R / h}$ & $\begin{array}{c}\text { Survey } \\
\text { Point } \\
\end{array}$ & $\underline{u R / h}$ & $\begin{array}{c}\text { Survey } \\
\text { Point } \\
\end{array}$ & $\underline{\mathrm{u} R / \mathrm{h}}$ \\
\hline Cochiti- 1 & 15 & $A-17$ & 17 & B- 8 & 18 & $L-1$ & 17 \\
\hline Cochiti- 2 & 16 & $A-18$ & 17 & $B-9$ & 18 & L- 2 & 18 \\
\hline Ponderosa & 20 & $A-19$ & 18 & $B-10$ & 18 & & \\
\hline Tesuque & 18 & $A-20$ & 19 & & & $N-1$ & 14 \\
\hline Santa Cruz & 13 & $A-21$ & 18 & $C-1$ & 21 & $\mathrm{~N}-2$ & 14 \\
\hline Taos-1 & 11 & $A-22$ & 17 & $C-2$ & 27 & & \\
\hline \multirow[t]{2}{*}{ Taos- 2} & 13 & A. 23 & 19 & C- 3 & 21 & PL- 1 & 16 \\
\hline & & A -24 & 25 & $C-4$ & 22 & PL- 2 & 18 \\
\hline$A-1$ & 18 & $A-25$ & 20 & $C-5$ & 19 & PL- 3 & 19 \\
\hline$A-2$ & 20 & A -26 & 19 & & & PL- 4 & 17 \\
\hline A- 3 & 18 & $A-27$ & 17 & $E-1$ & 13 & PL- 6 & 18 \\
\hline$A-4$ & 18 & A -28 & 18 & $E-2$ & 13 & PL- 7 & 18 \\
\hline$A-5$ & 19 & A -29 & 16 & E- 3 & 11 & PL- 8 & 17 \\
\hline A- 6 & 19 & $A-30$ & 17 & $E-4$ & 11 & PL... ? & 17 \\
\hline$A-7$ & 18 & $A-31$ & 15 & $E-5$ & 11 & PJ_- 10 & 16 \\
\hline$A-8$ & 18 & $A-32$ & 16 & $E-6$ & 10 & PL- 11 & 15 \\
\hline A- 9 & 18 & & & E- 7 & 9 & FL- 13 & 15 \\
\hline$A-10$ & 20 & $B-1$ & 17 & $E-8$ & 8 & PL- 14 & 16 \\
\hline$A-11$ & 19 & $B-2$ & 16 & $E-9$ & 8 & PL- 15 & 15 \\
\hline$A-12$ & 18 & $B-3$ & 19 & $E-10$ & 8 & PL- 16 & 14 \\
\hline$A-13$ & 18 & $B-4$ & 19 & & & PL- 17 & 15 \\
\hline A - 14 & 18 & $B-5$ & 17 & $\mathrm{~K}-1$ & 16 & PL- 19 & 15 \\
\hline$A-15$ & 18 & $B-6$ & 18 & $K-2$ & 16 & PL- 20 & 15 \\
\hline$A-16$ & 17 & B- 7 & & & & & \\
\hline
\end{tabular}


TABLE A-II

LOW ENERGY FIELD RADIATION MEASUREMEINS

Survey

Point

Cochiti - 1

Cochiti - 2

Ponderosa

Tesuque

Santa Cruz

Taos - 1

Taos - 2

A- 1

A- 2

A- 3

A- 4

A- 5

A. 6

A- 7

A- 8

A. 9

A -10

A- 11

A- 12

A- 13

A- 14

A- 15

A-16

A- 17

A -18

A -19

A- 20

A- 21

A- 22

A -23

A- 24

A- 25

A-26

A- 27

A -28

A- 29

A- 30

A- 31

A-32.

B- 1

B- 2

B- 3

B- 4

B- 5

B- 6

B- 7

B- 8

B- 9

B- 10
Gross Counts Per Minute

\begin{tabular}{|c|c|c|c|c|c|}
\hline Channel I & Channel 2 & Channel 3 & Channel 4 & Chaninel 5 & Channel 6 \\
\hline 561 & 467 & 445 & 630 & 2287 & 2619 \\
\hline 672 & 581 & 569 & 314 & 3027 & 32.83 \\
\hline 833 & 803 & 796 & 1199 & 2938 & 3350 \\
\hline 644 & 612 & 613 & 898 & 3361 & 3512 \\
\hline 489 & 357 & 333 & 470 & 1789 & 1927 \\
\hline 504 & 349 & 417 & 435 & 1600 & 1805 \\
\hline 555 & 410 & 386 & 541 & 2016 & 2265 \\
\hline 622 & 551 & 549 & 766 & 3117 & 3219 \\
\hline 697 & 646 & 593 & 831 & 3328 & 3451 \\
\hline 678 & 590 & 586 & 811 & 3332 & 3399 \\
\hline 660 & 616 & 610 & 898 & 3617 & 3646 \\
\hline 662 & 590 & 566 & 815 & 3403 & 3535 \\
\hline 677 & 614 & 566 & 827 & 3348 & 3502 \\
\hline 667 & 544 & 504 & 728 & 2948 & 3119 \\
\hline 743 & 606 & 600 & 810 & 3129 & 3201 \\
\hline 744 & 575 & 561 & 774 & 3182 & 3466 \\
\hline 764 & 586 & 554 & 758 & 3168 & 3489 \\
\hline 743 & 587 & 568 & 746 & 2985 & 3237 \\
\hline 725 & 526 & 503 & 679 & 2776 & 3088 \\
\hline 694 & 550 & 522 & 724 & 2971 & 3206 \\
\hline 723 & 596 & 586 & 823 & 3290 & 3523 \\
\hline 611 & 584 & 587 & 847 & 3225 & 3155 \\
\hline 636 & 591 & 580 & 845 & 3301 & 3330 \\
\hline 641 & 566 & 574 & 806 & 3270 & 3390 \\
\hline 614 & 558 & 562 & 807 & 3150 & 3195 \\
\hline 693 & 591 & 570 & 814 & 3204 & 3408 \\
\hline 711 & 582 & 560 & 855 & 3372 & 3645 \\
\hline 680 & 581 & 575 & 779 & 3056 & 3202 \\
\hline 563 & 573 & 570 & 791 & 3086 & 3144 \\
\hline 586 & 635 & 662 & 956 & 3710 & 3660 \\
\hline 605 & 685 & 962 & 1016 & 4155 & 4375 \\
\hline 584 & 560 & 544 & 807 & 3084 & 3226 \\
\hline 599 & 609 & 599 & 878 & 3330 & 3446 \\
\hline 586 & 617 & 616 & 895 & 3331 & 3343 \\
\hline 631 & 605 & 604 & 842 & 3194 & 3327 \\
\hline 592 & 525 & 502 & 712 & 2756 & 2982 \\
\hline 601 & 602 & 623 & 878 & 3119 & 3170 \\
\hline 550 & 456 & 454 & 640 & 2377 & 2482 \\
\hline 584 & 536 & 523 & 765 & 2810 & 2807 \\
\hline 531 & 529 & 530 & 789 & 3113 & 3136 \\
\hline 530 & 508 & 492 & 755 & 2948 & 3008 \\
\hline 620 & ó23 & 629 & 932 & 3526 & 3547 \\
\hline 601 & 569 & 550 & 839 & 3184 & 3323 \\
\hline 595 & 549 & 510 & 777 & 2965 & 3164 \\
\hline 663 & 592 & 567 & 839 & 3143 & 3379 \\
\hline 637 & 583 & 555 & 818 & 3021 & 3232 \\
\hline 613 & 584 & 558 & 810 & 3091 & 3314 \\
\hline 615 & 561 & 522 & 774 & 2940 & 3220 \\
\hline 614 & 563 & 546 & 852 & 3062 & 2956 \\
\hline
\end{tabular}


TABLE A-II (continued)

Survey

Point

$C-1$
$C-2$
$C-3$
$C-4$

C. 5

E- 1

$E-2$

E- 3

$E-4$

E- 5

$E-6$

E- 7

E- 8

E- 9

E-10

K - 1

$\mathrm{K}-2$

L- 1

L- 2

$N-1$

$N-2$

PL. 1

PL- 2

PL- 3

PL - 4

PL - 6

PL- 7

PL- 8

PL- 9

PL- 10

PL- 11

PL- 13

PL- 14

PL - 15

PL- 16

PL- 17

PL- 19

PI- 20

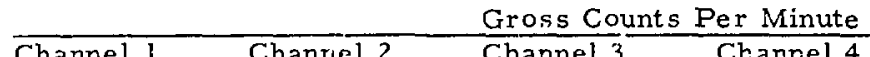

\begin{tabular}{|c|c|c|c|c|c|}
\hline Channel 1 & Chanriel 2 & Channel 3 & Channel 4 & Channel 5 & Channel 6 \\
\hline 593 & 657 & 656 & 1033 & 4039 & 3998 \\
\hline 640 & 688 & 666 & 1034 & 4076 & 4137 \\
\hline 605 & 637 & 615 & 968 & 3752 & 3846 \\
\hline 642 & 675 & 665 & 1017 & 3850 & 3946 \\
\hline 591 & 594 & 576 & 872 & 3367 & 3524 \\
\hline 420 & 320 & 262 & 373 & 1396 & 1491 \\
\hline 386 & 283 & 487 & 320 & 1145 & 1214 \\
\hline 383 & 274 & 465 & 312 & 1165 & 1244 \\
\hline 400 & 282 & 436 & 326 & 1181 & 1245 \\
\hline 433 & 342 & 295 & 416 & 1582 & 1660 \\
\hline 372 & 242 & 470 & 288 & 1012 & 1169 \\
\hline 428 & 281 & 480 & 307 & 1031 & 1210 \\
\hline 453 & 293 & 269 & 363 & 1204 & 1347 \\
\hline 418 & 237 & 452 & 263 & 934 & 1071 \\
\hline 422 & 272 & 499 & 316 & 1051 & 1238 \\
\hline 543 & 491 & 469 & 707 & 2796 & 2868 \\
\hline 583 & 478 & 452 & 642 & 2546 & 2663 \\
\hline 634 & 571 & 526 & 788 & 3049 & 3278 \\
\hline 634 & 595 & 551 & 828 & 3122 & 3232 \\
\hline 596 & 491 & 489 & 688 & 2664 & 2865 \\
\hline 587 & 510 & 502 & 696 & 2685 & 2878 \\
\hline 618 & 492 & 437 & 666 & 2569 & 2799 \\
\hline 653 & 567 & 519 & 794 & 3026 & 3230 \\
\hline 592 & 543 & 530 & 791 & 3171 & 3226 \\
\hline 542 & 497 & 486 & 725 & 2836 & 2893 \\
\hline 598 & 527 & 527 & 755 & 3016 & 3112 \\
\hline 623 & 514 & 510 & 728 & 2901 & 3080 \\
\hline 564 & 538 & 532 & 764 & 3103 & 3124 \\
\hline 568 & 530 & 517 & 754 & 2956 & 3109 \\
\hline 577 & 513 & 502 & 722 & 2795 & 2993 \\
\hline 606 & 517 & 511 & 716 & 2784 & 2991 \\
\hline 601 & 535 & 525 & 733 & 2818 & 3052 \\
\hline 591 & 509 & 515 & 700 & 2705 & 2930 \\
\hline 579 & 473 & 477 & 658 & 2557 & 2802 \\
\hline 540 & 426 & 426 & 609 & 2292 & 2474 \\
\hline 578 & 477 & 489 & 675 & 2572 & 2754 \\
\hline 604 & 516 & 514 & 734 & 2740 & 2979 \\
\hline 616 & 501 & 527 & 717 & 2768 & 3003 \\
\hline
\end{tabular}


TABLE A-III

\section{LAFPHA DATA RATIOS}

Survey

Point

Cochiti - 1

Cochiti - 2

Ponderosa

Tesuque

Santa Cruz

Taos - 1

Taos -2

A- 1

A- 2

A- 3

A- 4

A- 5

A- 6

A- 7

A- 8

A- 9

$A-10$

A-11

$A-12$

$A-13$

$A-14$

$A-15$

$A-16$

A -17

A -18

A- 19

A- 20

A- 21

A- 22

A- 23

A- 24

A- 25

A- 26

A- 27

A- 28

A- 29

A- 30

A- 31

A -32

B- 1

B- 2

B- 3

B- 4

B- 5

B- 6

B- 7

B- 8

B- 9

B- 10

\begin{tabular}{|c|c|}
\hline $\mathrm{Ch} 2 / \mathrm{Ch} \mathrm{l}$ & $\mathrm{Ch} 2 / \mathrm{Ch}_{3}$ \\
\hline 0.83 & 1.05 \\
\hline 0.86 & 1.32 \\
\hline 0.96 & 1.01 \\
\hline 0.95 & 1.00 \\
\hline 0.73 & 1.07 \\
\hline 0.69 & 0.84 \\
\hline 0.74 & 1.06 \\
\hline
\end{tabular}

0.89

0.93

0.87

0.93

0.89

0.91

0.82

0.82

0.77

0.77

0.79

0.73

0.79

0.82

0.96

0.93

0.88

0.91

0.85

0.82

0.85

0.86

1.08

1.13

0.96

1.02

1.05

0.96

0.89

I. 00

0.83

0.92

1.00

0.96

1.00

0.95

0.92

0.89

0.92

0.95

0.91

0.92

1.00

1.01

1.01
1.04

1.08

1. 01

1. 02

1.03

1.05

1.02

0.99

0.99

0.99

1. 04

1.01

1.01
Ratios of Observed Count Rates

Ch $2 / \mathrm{Ch} 6 \quad \mathrm{Ch} 5 / \mathrm{Ch} 4$

Ch $5 / \operatorname{Ch} 6$

0.18

0,18

0,24

0.17

0.19

0.19

0.18

3.63

3. 72

2. 45

3. 74

3. 81

3.68

3.73

0.87

0.92

0.88

0.96

0.93

0.89

0.89

\subsection{7}

0.19

0.17

4. 07

0.97

4.00

0.96

0.17

4. 11

0.98

0.17

0.18

0.17

0.19

0.17

0.17

0.18

0.17

0.17

0.17

0.19

4.03

4. 18

4. 05

0.99

0.96

4. 05

0.96

0.95

0.98

4. 11

0.92

4. 18

4.00

0.91

0.92

0.90

0.93

4. 10

4. 00

3. 81

3.91

0.18

0.17

0.17

0.16

0.18

0.18

0.17

0.16

0. 17

0.18

0.18

0.18

0.18

0.19

0.18

0.19

3. 90

3. 94

3. 94

3. 92

3. 90

3. 88

4. 09

3. 82

3. 79

3. 72

5. 79

3. 87

3. 55

3.71

3. 67

1.02

0.99

0.96

0.99

0.94

0.93

0.95

0.98

1.01

0.95

0.96

0.97

1.00

0.96

0.92

0.98

0.96

1.00

0.17

3.95

0.99

0.17

3. 90

0.98

0.18

3. 78

3. 79

0.17

0.18

3.82

3.75

3. 69

0.18

0. 17

3.82

3. 80

0.19
0.99

$0.96^{\circ}$

0.94

0.93

0.93

0.93

0.91 
Survey

Point

C. 1

C- 2

C. 3

C- 4

C- 5

E. 1

E- 2

E- 3

E- 4

E- 5

E- 6

E- 7

E- 8

E- 9

E- 10

K- 1

K- 2

L- 1

L- 2

N- 1

$N-2$

PL- 1

PL- 2

PL- 3

PL- 4

PL- 6

PL- 7

PL- 8

PL- 9

PL- 10

PL- 11

PL- 13

PL- 14

PL-15

PL-16

PL-17

PL- 19

PL- 20

Ratios of Observed Count Rates

\begin{tabular}{|c|c|c|c|c|}
\hline $\mathrm{Ch} 2 / \mathrm{Ch} 1$ & $\mathrm{Ch} 2 / \mathrm{Ch} 3$ & $\mathrm{Ch} 2 / \mathrm{Ch} 6$ & $\mathrm{Ch} 5 / \mathrm{Ch} 4$ & $\operatorname{Ch} 5 / \operatorname{Ch} 6$ \\
\hline 1.11 & 1.00 & 0.16 & 3.91 & 1.01 \\
\hline 1.08 & 1.03 & 0.17 & 3.94 & 0.99 \\
\hline 1.05 & 1.04 & 0.17 & 3.88 & 0.98 \\
\hline 1.05 & 1.02 & 0.17 & 3.79 & 0.98 \\
\hline 1.01 & 1.03 & 0.17 & 3.86 & 0.96 \\
\hline 0.76 & 1,22 & 0.21 & 3.74 & 0.94 \\
\hline 0.73 & 0,58 & 0.23 & 3.58 & 0.94 \\
\hline 0.72 & 0.59 & 0.22 & 3.73 & 0.94 \\
\hline 0.71 & 0.65 & 0.23 & 3.62 & 0.95 \\
\hline 0.79 & 1.16 & 0.21 & 3.80 & 0.95 \\
\hline 0.65 & 0.51 & 0.21 & 3.51 & 0.87 \\
\hline 0.66 & 0.59 & 0.23 & 3.36 & 0.85 \\
\hline 0.65 & 1.09 & 0.22 & 3.32 & 0.89 \\
\hline 0.57 & 0.52 & 0.22 & 3.55 & 0.87 \\
\hline 0.64 & 0.55 & 0.22 & 3.33 & 0.85 \\
\hline 0.90 & 1.05 & 0.17 & 3.95 & 0.97 \\
\hline 0.82 & 1.06 & 0.18 & 3.97 & 0.96 \\
\hline 0.90 & 1.07 & 0.17 & 3.37 & 0.93 \\
\hline 0.94 & 1.08 & 0.18 & 3.77 & 0.97 \\
\hline 0.82 & 1.00 & 0.17 & 3.87 & 0.93 \\
\hline 0.87 & 1.02 & 0.18 & 3.86 & 0.93 \\
\hline 0.80 & 1.13 & 0.18 & 3.86 & 0.92 \\
\hline 0.86 & 1.09 & 0.18 & 3.81 & 0.94 \\
\hline 0.92 & 1.02 & 0.17 & 4.01 & 0.98 \\
\hline 0.92 & 1.02 & 0.17 & 3.91 & 0.98 \\
\hline 0.88 & 1.00 & 0.17 & 3.99 & 0.97 \\
\hline 0.83 & 1.01 & 0.17 & 3.98 & 0.94 \\
\hline 0.95 & 1.01 & 0.17 & 4.06 & 0.99 \\
\hline 0.93 & 1.03 & 0.17 & 3.92 & 0.95 \\
\hline 0.89 & 1.02 & 0.17 & 3.87 & 0.93 \\
\hline 0.85 & 1.01 & $0 . i 7$ & 3.89 & 0.93 \\
\hline 0.89 & 1.02 & 0.18 & 3.84 & 0.92 \\
\hline 0.86 & 0.99 & 0.17 & 3.86 & 0.92 \\
\hline 0.82 & 0.99 & 0.17 & 3.89 & 0.91 \\
\hline 0.79 & 1.00 & 0.17 & 3.76 & 0.93 \\
\hline 0.83 & 0.98 & 0.17 & 3.81 & 0.93 \\
\hline 0.85 & 1.00 & 0.17 & 3.73 & 0.92 \\
\hline 0.81 & 0.95 & 0.17 & 3.86 & 0.92 \\
\hline
\end{tabular}


TABIE A-IV

${ }^{137}$ CESIUM, AND GROSS BETA ACTIVITIES IN SOIL

Sample

Location

\section{Taos}

Ponderosa

Cochiti

Santa Cruz

Tesuque

$$
\text { A - } 1
$$

A- 2

A- 3

A - 4

A- 5

A- 6

A- 7

A- 8

A- 9

A- 10

A- 11

A -12

A -13

A - 14

A -15

A- 16

A -17

A -18

A -19

A -20

A- 21

A- 22

A -23

A. 24

A -25

A -26

A -27

A- 28

A -29

A -30

A -31

A-32

B- 1

B- 2

B- 3

B- 4

B- 5

B- 6

B- 7

B- 8

B- 9

B -10

\section{${ }^{13^{7} \mathrm{Cs}, \mathrm{pCi} / \mathrm{g}}$}

$1.2 \pm 0.7$

$5.7 \pm 0.8$

$4.3 \pm 0.8$

$3.0 \pm 0.8$

$4.0 \pm 0.8$

$6.8 \pm 0.8$

$3.3 \pm 0.8$

$4.4 \pm 0.8$

$3.6 \pm 0.8$

$3.0 \pm 0.8$

3. $1 \pm 0.8$

2. $8 \pm 0.8$

$4.3 \pm 0.8$

$3.6 \pm 0.8$

$3.9 \pm 0.8$

$2.8 \pm 0.8$

$3.7 \pm 0.8$

$9.2 \pm 0.8$

$5.9 \pm 0.8$

$5.9 \pm 0.8$

$6.2 \pm 0.8$

$5.0 \pm 0.8$

$6.9 \pm 0.8$

2. $9 \pm 0.8$

3. $2 \pm 0.8$

$5.3 \pm 0.8$

$-$

$5.0 \pm 0.8$

$3.4 \pm 0.8$

$3.4 \pm 0.8$

$2.4 \pm 0.8$

$3.3 \pm 0.8$

$4.2 \pm 0.8$

2. $2 \pm 0.8$

$3.1 \pm 0.8$

$0.9 \pm 0.7$

$1.9 \pm 0.8$

$1.9 \pm 0.8$

$2.4 \pm 0.8$

$4.0 \pm 0.8$

$2.5 \pm 0.8$

$2.5 \pm 0.8$

2. $1 \pm 0.8$

$3.4 \pm 0.8$

$4.0 \pm 0.8$

$3.5 \pm 0.8$
Sample

$16.2 \pm 0.5$

$31.7 \pm 0.7$

$19.1 \pm 0.6$

$17.5 \pm 0.6$

$22.6 \pm 0.6$

$27.2 \pm 0.7$

$26.7 \pm 0.7$

$25.1 \pm 0.6$

$31.6 \pm 0.7$

$28.2 \pm 0.7$

$28.2 \pm 0.7$

$20.3 \pm 0.6$

$24.8 \pm 0.6$

$28.4 \pm 0.7$

$25.3 \pm 0.6$

$25.1 \pm 0.6$

$18.3 \pm 0.6$

$27.0 \pm 0.7$

$30.0 \pm 0.7$

$19.4 \pm 0.6$

$19.4 \pm 0.6$

$23.6 \pm 0.6$

$23.8 \pm 0.6$

$26.7 \pm 0.7$

$24.4 \pm 0.6$

$23.3 \pm 0.6$

lost

$23.8 \pm 0.6$

$20.9 \pm 0.6$

$18.8 \pm 0.6$

$26.0 \pm 0.7$

$27.5 \pm 0.7$

$23.7 \pm 0.6$

$17.4 \pm 0.6$

$22.2 \pm 0.6$

13. $1 \pm 0.5$

16. $8 \pm 0.5$

lost

$20.6 \pm 0.6$

$26.3 \pm 0.7$

$20.9 \pm 0.6$

$20.6 \pm 0.6$

$20.0 \pm 0.6$

$24.8 \pm 0.6$

23. $1 \pm 0.6$

$25.0 \pm 0.6$

$24.2 \pm 0.6$
Location

C- 1

${ }^{137} \mathrm{Cg}, \mathrm{pCi} / \mathrm{g}$

$2.9 \pm 0.8$

$3.6 \pm 0.8$

$2.5 \pm 0.8$

2. $4 \pm 0.8$

$3.5 \pm 0.8$

C. 5

E- 1

E- 2

E- 3

E- 4

E- 5

E- 6

E- 7

E- 8

E- 9

E- 10

K- 1

K- 2

L- 1

L- 2

N- 1

N- 2

PI- 1

PL- 2

PL- 3

PL - 4

PL- 6

PL- 7

PL- 8

PI- 9

PL - 10

PL- 11

PL- 13

PL - 14

PL- 15

PL- 16

PL- 17

PL- 19

PL-20
$2.2 \pm 0.8$

$1.4 \pm 0.8$

$1.7 \pm 0.8$

$$
--
$$

2. $1 \pm 0.8$

$0.9 \pm 0.7$

$1.3 \pm 0.8$

$1.0 \pm 0.7$

1. $5 \pm 0.8$

2. $1 \neq 0.8$

$3.5 \pm 0.8$

2. $3 \pm 0.8$

$3.1 \pm 0.8$

$3.9 \pm 0.8$

$1.6 \pm 0.5$

2. $0 \pm 0.8$

$2.6 \pm 0.8$

$2.4 \pm 0.8$

$1.5 \pm 0.8$

2. $8 \pm 0.8$

2. $3 \pm 0.8$

$2.2 \pm 0.8$

$3.0 \pm 0.8$

2. $9 \pm 0.8$

$2.2 \pm 0.8$

$2.4 \neq 0.8$

$4.3 \pm 0.8$

$4.0 \pm 0.8$

2. $1 \pm 0.8$

$1.8 \pm 0.8$

$1.1 \pm 0.7$

$2.4 \pm 0.8$
Gross $\beta, p C i / g$

$26.6 \pm 0.7$

$26.9 \pm 0.7$

$20.9 \pm 0.6$

$23.6 \pm 0.6$

$23.0 \pm 0.6$

$19.7 \pm 0.6$

$17.6 \pm 0.6$

$16.0 \pm 0.5$

lost

$$
--
$$

$15.8 \pm 0.5$

14. $1 \pm 0.6$

$13.6 \pm 0.6$

$13.4 \pm 0.6$

$13.6 \pm 0.6$

$13.5 \pm 0.6$

$21.5 \pm 0.7$

$16.4 \pm 0.7$

$16.6 \pm 0.7$

$26.5 \pm 0.8$

lost

$37.6 \pm 0.8$

$18.6 \pm 0.6$

$23.5 \pm 0.6$

$18.7 \pm 0.6$

$20.0 \pm 0.6$

$22.7 \pm 0.6$

$20.8 \pm 0.6$

$20.3 \pm 0.6$

$26.4 \pm 0.6$

$22.2 \pm 0.6$

$21.6 \pm 0.6$

$20.4 \pm 0.6$

$25.4 \pm 0.6$

$24.0 \pm 0.6$

$19.0 \pm 0.6$

$20.1 \pm 0.6$

$17.4 \pm 0.6$

$20.0 \pm 0.6$ 
Sample

$\underline{\text { Location(s) }}$

Taos

Ponderosa

Cochiti

Santa Cruz

Tesuque

A -1

A -2

A $-1 C$

A -2 C

A -12

A -3 C

A -15

A -16

A -17

A -18

A -21

A -23

A -24

A -4 C

A -29

A -5 C

A -31

B - 1 C

B-4

B -5

B-6

B-8

C- $1 \mathrm{C}$

E-1C

E-2C

E-3C

$\mathrm{K}-\mathrm{IC}$

L- IC

$N-1 C$

PL- $1 C$

PL-2C

PL-3C

PL-4C

PL-5C

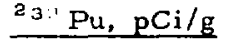

$0.02 \pm 0.01$

$0.03 \pm 0.01$

$0.07 \pm 0.08$

$0.03 \pm 0.02$

$0.11 \pm 0.02$

$0.04 \pm 0.01$

$0.01 \pm 0.01$

$0.10 \pm 0.03$

$0.22 \pm 0.16$

$0.01 \pm 0.01$

$0.09 \pm 0.06$

$0.03 \pm 0.01$

$0.04 \pm 0.01$

$0.03 \pm 0.01$

$0.03 \pm 0.01$

$0.03 \pm 0.01$

$0.04 \pm 0.01$

$0.01 \pm 0.01$

$0.06 \pm 0.02$

$0.04 \pm 0.01$

$0.06 \pm 0.03$

$0.02 \pm 0.01$

$0.08 \pm 0.05$

$0.04 \pm 0.01$

$0.02 \pm 0.01$

$0.01 \pm 0.01$

$0.01 \pm 0.01$

$0.12 \pm 0.07$

$1.00 \pm 0.60$

$<0.01 \pm 0.01$

$0.60 \pm 0.30$

$0.02 \pm 0.01$

$0.04 \pm 0.02$

$0.04 \pm 0.04$

$0.15 \pm 0.04$

$0.27 \pm 0.04$

$0.05 \pm 0.02$

$0.39 \pm 0.14$

$0.04 \pm 0.02$
${ }^{2} 3{ }^{3} \mathrm{Pu}, \mathrm{pCi} / \mathrm{g}$

$$
\begin{aligned}
& 0.04 \pm 0.03 \\
& 0.01 \pm 0.01 \\
& 0.50 \pm 0.40 \\
& 0.06 \pm 0.04 \\
& 0.05 \pm 0.02
\end{aligned}
$$

$<0.01 \pm 0.01$

$<0.01 \pm 0.01$

$0.19 \pm 0.08$

$0.60 \pm 0.40$

$<0.01 \pm 0.01$

$0.30 \pm 0.20$

$<0.01 \pm 0.01$

$<0.01 \pm 0.01$

$<0.01 \pm 0.01$

$<0.01 \pm 0.01$

$<0.01 \pm 0.01$

$<0.01 \pm 0.01$

$<0.01 \pm 0.01$

$0.01 \pm 0.01$

$<0.01 \pm 0.01$

$0.03 \pm 0.03$

$<0.01 \pm 0.01$

$0.20 \pm 0.14$

$0.01 \pm 0.004$

$<0.01 \pm 0.01$

$0.01 \pm 0.002$

$<0.01 \pm 0.01$

$0.30 \pm 0.20$

$1.20 \pm 1.00$

$<0.01 \pm 0.01$

$0.40 \pm 0.30$

$0.05 \pm 0.02$

$0.01 \pm 0.01$

$0.01 \pm 0.01$

$<0.01 \pm 0.01$

$0.02 \pm 0.01$

$0.01 \pm 0.01$

$0.05 \pm 0.04$

$<0.01 \pm 0.01$
$242 \mathrm{Am}, \mathrm{pCi} / \mathrm{g}$

$0.09 \pm 0.08$

$0.09 \pm 0.03$

$0.04 \pm 0.02$

$0.04 \pm 0.02$

$0.03 \pm 0.02$

$0.06 \pm 0.02$

$0.09 \pm 0.03$

$0.90 \pm 0.30$ $<0.01$

$0.09 \pm 0.02$

$0.03 \pm 0.02$

$0.04 \pm 0.02$

$0.04 \pm 0.02$

$0.02 \pm 0.02$

$0.06 \pm 0.01$

$0.03 \pm 0.02$

$0.04 \pm 0.01$

$<0.01 \pm 0.01$

$0.25 \pm 0.09$

$0.04 \pm 0.01$

$0.06 \pm 0.02$

$0.03 \pm 0.02$

$0.12 \pm 0.06$

$0.15 \pm 0.07$

$0.01 \pm 0.01$

0. $16 \pm 0.09$

$0.04 \pm 0.03$

$0.05 \pm 0.02$

$0.06 \pm 0.02$

$0.08 \pm 0.04$

$<0.01 \pm 0.01$

$0.03 \pm 0.02$

$0.04 \pm 0.02$

$0.03 \pm 0.01$

$0.04 \pm 0.02$

$<0.01 \pm 0.01$

$0.03 \pm 0.01$

$0.07 \pm 0.02$

$0.05 \pm 0.01$

\footnotetext{
"Sample location notation with an alpha character followed by a number indicates an individual sample; e.g., A-1; where the number is followed by the alphi character "C"; e.g., A-1C, a composite of individual samples is indicated.
} 
TABLE A-VI

URANIUM MEASUREMENTS IN SOIL

Composited \& Individual Sample Location (s)
Total Uranium $\mu g / g$ of Sample

0.28

1.50

1.06

0.52

1. 20

0.61

0.33

1.13

0.71

0.65

0.58

0.65

0.39
Composited \& Individual Sample Location(s)

\section{K- $1 \mathrm{C}$}

L-1C

N-IC

PL-1 C

PL-2 C

PL-3 C

PL- $4 \mathrm{C}$

PL-5 C

Taos

Ponderosa

Cochiti

Santa Cruz

Tesuque
Total Uranium $\mu \mathrm{g} / \mathrm{g}$ of Sample
0.65
0.60
0.75
0.56
0.39
0.39
0.37
0.41
0.16
1. 24
0.18
0.65
0.65

Estimated single 8 tandard deviation due to measurement, $0.04 \mathrm{\mu g} / \mathrm{g}$.

TABLE A-VII

TRITIUM, ${ }^{137}$ CESIUM, AND GROSS BETA ACTIVITIES IN VEGETATION

Sample

Location

Taos

Ponderosa

Cochiti

Santa Cruz

Tesuque

A- 1

A- 2

A- 3

A- 4

A- 5

A. 6

A- 7

A- 8

A- 9

$A=10$

A- 11

A-12

$A=13$

A-14

A- 15

A-16

A- 17

A- 18

A- 19

A-20

A-21

A- 22

A- 23

A-24.

A -25

A-26

A -27

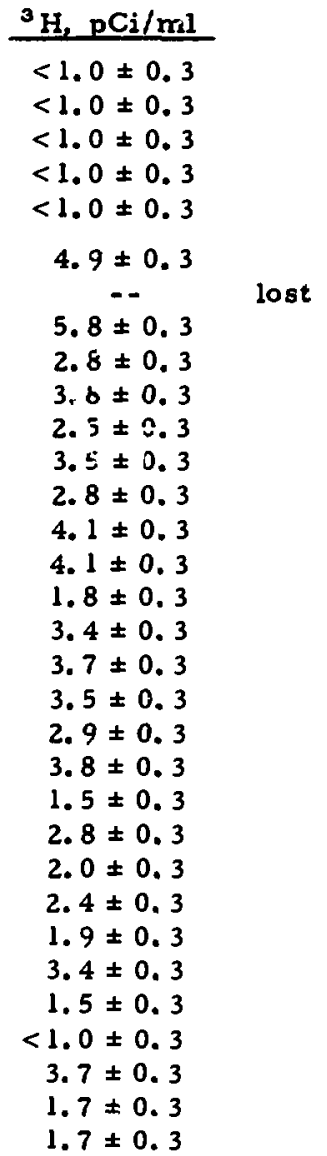

\begin{tabular}{c}
$23 \mathrm{C}_{s_{1}} \mathrm{pCi} / \mathrm{g}$ \\
\hline $2.4 \pm 0.3$ \\
$2.3 \pm 0.4$ \\
$1.3 \pm 0.3$ \\
$0.5 \pm 0.4$ \\
$1.7 \pm 0.5$ \\
$0.8 \pm 0.4$ \\
$1.5 \pm 0.5$ \\
$1.1 \pm 0.3$ \\
$3.4 \pm 0.4$ \\
$1.4 \pm 0.3$ \\
$2.2 \pm 0.4$ \\
$1.4 \pm 0.3$ \\
$0.5 \pm 0.4$ \\
$1.7 \pm 0.5$ \\
$0.9 \pm 0.6$ \\
$1.2 \pm 0.5$ \\
$0.7 \pm 0.5$ \\
$1.0 \pm 0.4$ \\
$0.5 \pm 0.5$ \\
$1.2 \pm 0.5$ \\
$1.4 \pm 0.6$ \\
$1.8 \pm 0.5$ \\
$1.6 \pm 0.5$ \\
$0.9 \pm 0.6$ \\
$6.7 \pm 1.3$ \\
$1.3 \pm 0.8$ \\
$2.1 \pm 0.8$ \\
$1.6 \pm 0.7$ \\
$3.7 \pm 0.8$ \\
$1.2 \pm 0.6$ \\
$1.0 \pm 0.4$
\end{tabular}

Gross $\beta, p C i / g$

$4.6 \pm 0.2$

4. $3 \pm 0.2$

4. $2 \pm 0.2$

$5.0 \pm 0.2$

$5.1 \pm 0.2$

$4.6 \pm 0.3$

$$
--
$$

$4.3 \pm 0.3$

4. $1 \pm 0.2$

$5.7 \pm 0.3$

4. $4 \pm 0.2$

$4.7 \neq 0.3$

$4.7 \pm 0.2$

$4.9 \pm 0.3$

$4.4 \pm 0.3$

4. $1 \pm 0.4$

$4.3 \pm 0.3$

4. $2 \pm 0.3$

$2.1 \pm 0.2$

$3.0 \pm 0.3$

4. $0 \pm 0.3$

3. $9 \pm 0.3$

2. $3 \pm 0.2$

$5.7 \pm 0.3$

$4.4 \pm 0.3$

$6.0 \pm 0.6$

$5.1 \pm 0.4$

$5.7 \pm 0.4$

$5.9 \pm 0.4$

$5.8 \pm 0.4$

4. $9 \pm 0.3$

$4.2 \pm 0.2$ 
TABLE A-VII (continued)

\begin{tabular}{|c|c|}
\hline $\begin{array}{c}\text { Sample } \\
\text { Location } \\
\end{array}$ & ${ }^{3} \mathrm{H}, \mathrm{pCi} / \mathrm{ml}$ \\
\hline$A-28$ & $2.0 \pm 0.3$ \\
\hline$A-29$ & $2.0 \pm 0.3$ \\
\hline$A-30$ & $1.6 \pm 0.3$ \\
\hline$A-31$ & $1.7 \pm 0.3$ \\
\hline A- 32 & $<1.0 \pm 0.3$ \\
\hline$B-1$ & $3.1 \pm 0.3$ \\
\hline B- 2 & $1.3 \pm 0.3$ \\
\hline$B-3$ & $1.2 \pm 0.3$ \\
\hline B- 4 & $1.1 \pm 0.3$ \\
\hline$B-5$ & $3.5 \pm 0.3$ \\
\hline$B-6$ & $3.5 \pm 0.3$ \\
\hline B- 7 & $3.5 \pm 0.3$ \\
\hline B- 8 & $3.7 \pm 0.3$ \\
\hline B- 9 & $1.2 \pm 0.3$ \\
\hline$B-10$ & $2.8 \pm 0.3$ \\
\hline$C-1$ & $1.3 \pm 0.3$ \\
\hline$C-2$ & $2.8 \pm 0.3$ \\
\hline$C-3$ & $1.3 \pm 0.3$ \\
\hline $\mathrm{C}-4$ & $1.6 \pm 0.3$ \\
\hline$c-5$ & $1.3 \pm 0.3$ \\
\hline$E-1$ & $1.4 \pm 0.3$ \\
\hline$E-2$ & $8.0 \pm 0.3$ \\
\hline E- 3 & $1.3 \pm 0.3$ \\
\hline$E-4$ & $2.4 \pm 0.3$ \\
\hline$E-5$ & $1.7 \pm 0.3$ \\
\hline$E-6$ & $<1.0 \pm 0.3$ \\
\hline$E-7$ & $<1.0 \pm 0.3$ \\
\hline E- 8 & $1.3 \pm 0.3$ \\
\hline$E-9$ & $1.9 \pm 0.3$ \\
\hline$E-10$ & $1.7 \pm 0.3$ \\
\hline $\mathrm{K}-1$ & $4.6 \pm 0.3$ \\
\hline $\mathrm{K}-2$ & $5.8 \pm 0.3$ \\
\hline L-1 & $5.8 \pm 0.3$ \\
\hline$L-2$ & $5.6 \pm 0.3$ \\
\hline$N-1$ & $4.7 \pm 0.3$ \\
\hline$N-2$ & lost \\
\hline PL- 1 & $4.3+0.3$ \\
\hline PI- 2 & $9.6 \pm 0.3$ \\
\hline PJ - 3 & $6.9 \pm 0.3$ \\
\hline PL- 4 & $\ldots$ \\
\hline PL- 6 & $8.1 \pm 0.3$ \\
\hline PL- 7 & $5.5 \pm 0.3$ \\
\hline PL- 8 & $2.4 \pm 0.3$ \\
\hline PL- 9 & $2.8 \pm 0.3$ \\
\hline PL-10 & $2.8 \pm 0.3$ \\
\hline PL-11 & $4.6 \pm 0.3$ \\
\hline PL- 13 & $5.2 \pm 0.3$ \\
\hline PL- 14 & $3.6 \pm 0.3$ \\
\hline PL- 15 & $3.5 \pm 0.3$ \\
\hline PL-16 & $<1.0 \pm 0.3$ \\
\hline PL- 17 & $<1.0 \pm 0.3$ \\
\hline PL-19 & $2.5 \pm 0.3$ \\
\hline PL-20 & $2.4 \pm 0.3$ \\
\hline
\end{tabular}

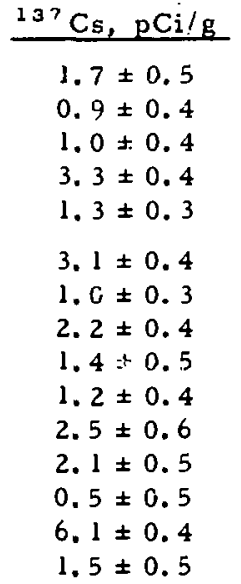

$3.0 \pm 0.4$

$0.8 \pm 0.4$

$0.5 \pm 0.5$

$1.1 \pm 0.5$

$1.3 \pm 0.4$

$1.7 \pm 0.5$

$0.6 \pm 0.3$

$1.0 \pm 0.3$

$0.5 \pm 0.4$

$1.2 \pm 0.6$

$0.8 \pm 0.3$

$1.3 \pm 0.3$

$1.7=0.4$

$1.1 \pm 0.2$

$1.2 \pm 0.4$

$6.4 \pm 0.9$

$0.3 \pm 0.4$

$0.7 \pm 0.3$

$1.5 \pm 0.5$

$9.8 \pm 0.9$

$3.7 \pm 0.6$

$0.6 \pm 0.4$

$0.8 \pm 0.6$

$1.8 \pm 0.3$

lost

$$
--
$$

1. $3 \pm 0.3$

3. $7 \pm 1.2$

1. $3 \pm 0.4$

$5.6 \pm 1.0$

$0.7 \pm 0.3$

2. $3 \pm 0.7$

2. $5 \pm 0.4$

$4.1 \neq 0.9$

$0.1 \pm 0.4$

$5.2 \pm 1.2$

$0.7 \pm 0.3$

$0.5 \pm 0.4$

$3.6 \pm 0.8$
Gross $\beta, p C i / g$

$4.7 \pm 0.3$

$3.5 \pm 0.2$

$3.5 \pm 0.2$

$5.2 \pm 0.2$

$5.2 \pm 0.3$

$6.0 \pm 0.3$

$5.0 \pm 0.2$

$4.4 \pm 0.2$

$5.9 \pm 0.3$

$5.8 \pm 0.3$

$5.8 \pm 0.3$

$4.5 \pm 0.3$

$5.6 \pm 0.3$

$4.7 \pm 0.2$

$5.0 \pm 0.3$

$6.7 \pm 0.3$

$4.3 \pm 0.2$

$5.1 \pm 0.3$

$5.0 \pm 0.4$

$3.7 \pm 0.3$

$4.0 \pm 0.2$

$3.8 \pm 0.2$

$4.2 \pm 0.2$

$3.8 \pm 0.2$

$3.5 \pm 0.3$

4. $3 \pm 0.2$

13. $4 \pm 0.4$

$6.5 \pm 0.3$

5. $3 \pm 0.2$

$5.4 \pm 0.3$

6. $2 \pm 0.5$

$2.7 \pm 0.2$

$4.7 \pm 0.3$

$3.8 \pm 0.3$

$15.7 \pm 0.4$

3. $2 \pm 0.2$

$5.0 \pm 0.3$

$3.0 \pm 0.3$

$3.9 \pm 0.2$

$--$

$3.8 \pm 0.2$

$20.7 \pm 0.9$

$4.2 \pm 0.3$

$19.4 \pm 0.9$

$2.9 \pm 0.2$

$17.0 \pm 0.6$

$5.6 \pm 0.3$

$21.4 \pm 0.7$

$4.7 \pm 0.2$

22. $7 \pm 0.8$

$5.0 \pm 0.2$

$0.3 \pm 0.1$

$14.5 \pm 0.5$ 
PLUTONIUM AND AMERICIUM ACTIVITIES IN VEGETATION

Composited \& Individual
Sample Location(s)

A-1C
A-2C
A-3C
A-4C
A-5C
A-6C
A-7C
A-8C
B-1C
B-2C
C-1C
E-1C
E-2C
K-1C
L-1C
N-1C
PL-1C
PL-2C
PL-3C
PL-4C
Taos
Ponderosa
Cochiti
Santa Cruz
Tesuque

ass $\mathrm{Pu}_{1}, \mathrm{pCi} / \mathrm{g}$

$0.005 \pm 0.002$

$0.004 \pm 0.001$

$0.009 \pm 0.001$

$0.012 \pm 0.004$

$0.004 \pm 0.001$

$0.003 \pm 0.001$

$0.004 \pm 0.001$

$0.006 \pm 0.001$

$0.006 \pm 0.001$

$0.005 \pm 0.002$

$0.002 \pm 0.001$

$0.002 \pm 0.001$

$0.034 \pm 0.015$

$0.002 \pm 0.001$

$0.004 \pm 0.001$

$0.008 \pm 0006$

$0.017 \pm 0.002$

$0.016 \pm 0.002$

$0.058 \neq 0.007$

$0.012 \neq 0.005$

$0.002 \pm 0.001$

$<0.001 \pm 0.001$

$0.003 \pm 0.001$

$0.003 \pm 0.001$

$0.002 \pm 0.001$ a38 Pu, pCiíg

$0.004 \pm 0.002$

$0.003 \pm 0.001$

$0.003 \pm 0.001$

$0.003 \pm 0.002$

$<0.001 \pm 0.001$

$0.003 \pm 0.001$

$<0.001 \pm 0.001$

$<0.001 \pm 0.001$
$0.007 \pm 0.003$
$0.005 \pm 0.004$

$<0.001 \pm 0.001$

$0.003 \pm 0.002$

$0.030 \pm 0.020$

$0.002 \pm 0.001$

$<0.001 \pm 0.001$

$0.001 \pm 0.001$

$0.003 \pm 0.001$

$0.003 \pm 0.001$

$<0.001 \pm 0.001$

$0.005 \pm 0.003$

$0.005 \pm 0.002$

$0.004 \pm 0.002$

$0.002 \pm 0.001$

$0.004 \pm 0.002$

$0.004 \pm 0.002$
241 Am, pCi/g

$0.140 \pm 0.030$

$0.006 \pm 0.001$

$0.004 \pm 0.001$

$0.007 \pm 0.002$

$0.009 \pm 0.004$

$0.008 \pm 0.002$

$0.010 \pm 0.003$

$0.021 \pm 0.009$

$0.006 \pm 0.001$

$0.012 \pm 0.002$

$0.004 \pm 0.001$

$0.007 \pm 0.001$

$0.029 \pm 0.007$

$0.006 \pm 0.002$

$0.006 \pm 0.002$

$0.016 \pm 0.003$

$0.010 \pm 0.003$

$0.031 \pm 0.008$

$0.057 \pm 0.011$

$0.032 \pm 0.007$

$0.011 \pm 0.003$

$0.012 \pm 0.005$

$0.003 \pm 0.001$

$0.003 \pm 0.001$

$0.009 \pm 0.003$

TABLE A-IX

URANIUM MEASUREMENTS IN VEGETATION

Composited \& Individual
Sample Losation(s)

A- $1 \mathrm{C}$

$A-2 C$

A-3C

$A-4 C$

$A-5 C$

A-6C

$A \cdot 7 \mathrm{C}$

A $-8 \mathrm{C}$

B- $1 \mathrm{C}$

B-2C

C- $1 \mathrm{C}$

E-1C

E-2C
Total Uranium

ug/g or Sample
0.10
0.27
0.10
0.07
0.07
0.07
0.04
0.12
0.12
0.10
0.07
0.04
0.38

Composited \& Individual Sample Location(a)

\section{$\mathrm{K}-1 \mathrm{C}$ \\ L-1C \\ N-1C}

PL-1C

PL-2C

PL-3C

PL-4C

Tars

Fonderosa

Cochiti

Tesuque

Santa Cruz
Total Uranium $\underline{\mathrm{g} / \mathrm{g} \text { of Sample }}$
0.02
0.07
0.15
0.05
0.11
0.10
0.20
0.02
$<0.02$
0.05
0.04 lost

\footnotetext{
Estimated single standard deviation due to measurement, $0.04 \mu \mathrm{g} / \mathrm{g}$.
} 


\section{OFFICE MEM!ORANDUM}

To : Harry S. Jordan, Group Leader, $\mathrm{H}-8$

DATE, Aug. 22, 1972

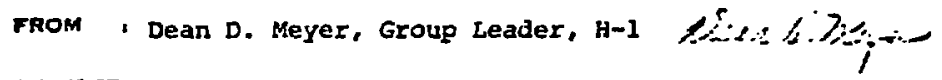

SUBJECT: RECORDS SEARCA: CONTAMINATION REPORT, UNNEEDEO REAL PRORERTY

SYMBOL : $\mathrm{H}-1-72-225$

A records search was made to determine the radioactive contamination history of the parcels of land A, B, C, E, I, K, and N listed in the request from Blackwell to Agnew, dated March 25, 1971.

In this search, records in Groug $H-1$ were examined and tail and Records was requested to provide records which the Laboratory had originated on the subject.

The foliowing files were obtained from Mail and Records:

"Acreage Boundaries"

"Demolition of Buildings"

"Denolition of Abandoned Lab Structures" (safety relating to)

"Contaminated Dumps and Haste Disposal"

"Transfer of Real Property or Land"

"Peximeter Safety Surveys".

In addition, the following i-Division records were consulted:

LA-4562, "Plutoniun and Strontium in Soil in Los Alamos, Espanola, and Santa Ee, New Mexico, Areas"

Pueblo Canyon Test Mells, Metes and Bounds, Description and Access Easements, Zia Company drawing 2-4226, two sheets, datad 8-11-66

LA-4561, "Plutorium in Stream Channel Alluviun in Los Alanos Area, New Mexico".

The records search indicated that with the exception of Area $C$, no detectable radiuactive contamination (cortable survey instruments) was present. Area $C$ has a stream bed into which treated waste water was discharged for a nurber of years. The Laboratory has an easement on the channel and this should be retained.

The findings of the record starch are supported by the personal experience of several members of Group $5-I$ who have been with the Laboratozy up to 27 yedrs and they are sure that the areas in question were not laboratory sites and that buriai sites were not established in any of the areas.

DDH/eh

Fig. A-1. 